\title{
LIETUVIŲ KARYBA XIII a.
}

\author{
Darius Baronas
}

\section{IVADAS}

KARAS - reiškinys, kurio žmonija kone labiausiai stengiasi išvengti, tačiau jis eina nuo žmonijos istorijos aušros. Jo permanentiškumas įdomus ir kontraversiškas. Karas nėra nekaltas vaikų žaidimas, tai - organizuota veikla, kuria tam tikrais veiksmais siekiama atimti kitam žmogui tai, kas jam brangiausia - gyvybę. Karo laukas - visa visuomené. Vadinasi, karas nèra paprastas kultūros reiškinys.

Vargu ar galime nustatyti prievartos vartojimo žmonių tarpusavio santykiuose pradžią, tačiau karo tikraja to žodžio prasme, ko gero, galime. Visų pirma ne visos visuomenès yra išgyvenusios jị: karo nežino šiaurès eskimai, nežino ir paleolito medžiotojai, žvejai. Senosiose civilizacijose karas kyla, anot Lewio Mumfordo, kaip galios sutelkimo mieste padarinys, sutampantis su ryškesne socialine stratifikacija ${ }^{1}$. Karas, būdamas civilizacijos palydovas ir pranašas, persiėmęs jos bruožų, yra kultūrinių išradimų pritaikymo plataus masto prievartai veiksnys.

Šiuolaikinè karo samprata neturètų temdyti kitokio supratimo, ji turètų padèti suvokti esmę: kas yra taika, kas yra karas, ar taika tik karo nebuvimas, ar normali būsena.

Paminėjus kai kuriuos bendrus bruožus, negalima nutylèti, kad karas - tai konfliktas. Konfliktinę situaciją reikia spręsti, o parinkus sprendimo būdą galima ši tą pasakyti apie konfliktuojančias visuomenes.Samprata "kitas" ar samprata "priešas" gali egzistuoti, bet viena pati ji nėra priežastis vaišintis ginklais. Juk dažniausiai karas kariaujamas dẻl ekonominių tikslų, o ekonomika yra karo variklis.

Žmogus nèra tobula būtybe், todèl įmanomas kryptingas agresyvumo sutelkimas, kas faktiškai ir padaryta.

Lietuvių istorikai domisi ankstyvaisiais Lietuvos istorijos amžiais, tad ir karo tema nèra nauja.

\footnotetext{
1 Mumford L.The City in History. N.Y. 1989. p.42: "Once the city came into existence,with its collective increase in power in every departament this whole situation underwent a change. Instead of raids and sallies for single victims mass extermination and mass destruction came to prevail”. 
Nors apie lietuvių kovas, ypač su kryžiuočiais, yra daug rašyta, tačiau lietuvių karybos tyrinèjimai nèra gausūs. Ši tema dažniausiai būdavo gvildenama apibendrintai, tarsi politine istorijos iliustracija, o traktuojama laisvai leidžiant ịsivyrauti nuotaikoms ir nereflektuotiems prioritetams. Tokios krypties pavyzdys būtų Antano Kučinsko nuostata, kuriam pagrindinis klausimas tiriant, pvz., Strẻvos ar Rūdavos mūšius, - kas laimëjo? Kronikininkų subjektyvumą, kuris "neretai kronikos autorių nuveda nuo tikslaus ir teisingo ịvykių vaizdavimo: savuosius laimèjimus didina, o pralaimejjimus mažina" ${ }^{2}$, pasirinkdamas kaip savo kritikos išeities tašką, jis prieina išties, švelniai tariant, prie keistų išvadų: "po Strẻvos mūšio Ordinui", matyt, trūko jëgų ir todèl jis pasitraukè, o gal net buvo lietuvių sumuštas" . Bet "iš to fakto, kad nè viena kronika neužrašè mūšio eigos ir kad iš Ordino pusès krito tokie žymūs vyrai, tenka pasidaryti išvadą, kad kautynès išèjo kryžiuočių nenaudai” " . Neargumentuoto lietuvių didvyriškumo atšvaitai kartais švysteli net ir labai rimtų istorikų raštuose. Antai Zenono Ivinskio nuomone, "tie tolimi lietuvių žygiai ị rytus buvo lyg savotiškas savo protèvių gyvenviečių ir jų etninių likučių ieškojimas" . Nors istorikui savo subjektyvaus požiūrio ir traktuotės neimmanoma išvengti, vis dẻlto argumentus remiant gausiais šaltiniais bei Lietuvos istorijos kontekstualiu regèjimu panašių nuomonių nesolidumas tampa akivaizdus. Toks principas, kai argumentuojama šaltiniais, o ne nuomone, reprezentuojamas Henriko Lownianskio, Edvardo Gudavičiaus, Alvydo Nikžentaičio ir kt. darbuose, kuriuose ir karybos klausimai aiškinami ne vien per karybą, bet ir atsižvelgiant ị visuomenès kitimą.

Remdamasis Henriko Latvio, Petro Dusburgiečio, Vygando Marbugiečio, Livonijos eiliuotaja kronikomis bei rusų metraščiais, nesutelkiu pagrindinio dėmesio ị klausimą, kas mūšį laimejjo ar pralaimejo: juk nesijaučiu galịs geriau už kronikininką žinoti, kaip buvo iš tiesų, daugiau dèmesio kreipiu ị tai, kas yra parašyta, galbūt net perdaug tuo pasikliaudamas. Turedamas omeny minètus pavojus, nesu visiškai tikras pats ju išvengęs, tačiau drịstu rašyti, nors negarantuoju, kad aukšti pažadai išsipildys.

\footnotetext{
${ }^{2}$ Kučinskas A.Kęstutis. V., 1988, p.44.

${ }^{3}$ Ten pat, p.60.

${ }^{4}$ Ten pat, p.83.

${ }^{5}$ Ivinskis Z.Lietuvos istorija (toliau - Istorija). V., 1991, p.159.
} 
Pagrindinis šio straipsnio tikslas - išsiaiškinti, kokie lietuviai kariavo ir kaip kariavo.

Pabaltijo genčių taryba XIII a., tai akcentuojama ir istorinëje literatūroje, tarpusavyje per daug nesiskyrẻ, todèl šiame straipsnyje cituojami šaltiniai, liečiantys vien lietuvius. Dèl XIII a. lietuvius ištikusio likimo jų karyba nenustojo vystytis. Tai ir yra objektyvaus pasirinkimo priežastis.

Straipsnio pavadinimas "Lietuvių karyba XIII a." yra užuomina, kad nesiekiama aprašyti XIII a. karų, o mėginama suprasti, kas yra karas XIII a. Lietuvoje. Kodèl šiame amžiuje? XIII a. būdingiausi du aspektai. Europos mastu galime skirti civilizaciją ir barbariškumą, pastarasis, be abejo, būdingas Lietuvai. Didžiojo tautų kraustymosi laikais ir iki pat XI a. barbarai veržèsi į buvusias Romos valdas, o Europos ekspansijos amžiais ne tiek Lietuva atrado, kuri, anot Henriko Paszkiewicziaus, "daug daugiau norèjo ir privalejjo imti iš ją supančio pasaulio, nei galëjo duoti”", kiek ji buvo atrasta. Vokiečiu vykdoma "veržimosi ị Rytus"” politika buvo naujas dalykas visame Pabaltijo regione. Erico Christianseno teigimu, kryžiaus žygiai į Lietuvą nebuvo tokie impozantiški ir brangūs kaip ị Šventają Žemę, tačiau pakitimų, kuriuos jie sukèlè, pėdsakai nėra visiškai išnykę ir dabar ${ }^{8}$. Visu pirma tai nauja valdžios koncepcija, kurios regionini netapatumą galima pailiustruoti Henriko Latvio mintimi, jog rusų carai užkariauja kitas gentis ne tam, kad pajungtụ i krikščionių tikèjimą, bet kad jos mokètų duokles ir pinigus9. Sis vienas iš trijų Z.Ivinskio išryškintų permanentinių Lietuvai geopolitinių veiksnių yra tarytum iššūkis, o atsakas i ji rodo visuomenès brandumą. Antra, XIII a. susidariusi Lietuvos monarchija žymi gentinès visuomenès transformaciją i naują valstybinę - kokybę. Taigi dar kartą - kodẻl būtent karyba?

\footnotetext{
${ }^{6}$ Paszkewicz H. Jagillonowie a Moskwa, t. I. W., 1933, p.26.

7 žr. Gudavičius E. Lietuvos valstybès susidarymo reikšmė Vokietijos "veržimesi i Rytus". // Lituanistica, 1990. Nr.3, p.21-29.

${ }^{8}$ Christiansen E. The Northern Crusades (toliau - The Northern). Minneapolis. 1980, p.2.

${ }^{9}$ Genrich Latvijskij. Chronika Livonii. M. L., 1938. Henrici Chronison Livoniae (toliau HCL), p.341: "Est enim consuetudo regum Ruthenorum, ut quamcungue gentem expugnaverint, non Fidei christiane sed ad solvendum sibi tribulum et pecuniam subiugare".
} 


\section{Karingumas kaip pyktis}

\section{Grobio žygis}

Baltų gentis VI a. gotų istorikas Jordanas apibūdina kaip taikingas ${ }^{1}$, IX a. anglosaksų keliautojas Vulfstanas, svečiavęsis Vyslos Žemupio prūsų žemėse, teigia, kad tarp jų kyla daug karų ${ }^{2}$. XIII a. ne retenybe prūsų antpuoliai ị lenkų žemes, lietuvių - ị livoniečių, rusų ir kitų tolimesnių kaimynų kraštus. Apie ankstesnių nei XIII a. laikų karybą rašytiniai šaltiniai tyli, o apie lietuvių karybą XIII a. galima pasakyti ši tą konkretaus.

Konstatuodami tam tikrą karybos raidos akivaizdumą, pirmiausia turime atkreipti dẻmesi i c pagrindinius veiksnius, tarp kurių yra raktas, leidžiantis aiškinti pokyčių esmę. Apskritai gentinès visuomenės forma yra bendruomené. Individo priklausymas giminei yra vienas pagrindinių visų socialinių sluoksnių, tiek nobilių, tiek laisvụjų laukininkų, bruožų. Petras Dusburgietis kariniu požiūriu prūsų visuomenę skirsto ị raitelius kilminguosius ir péstininkus - nekilminguosius ${ }^{3}$. Šis tikrovę atitinkantis skirstymas taip pat žymi du pagrindinius karinių pajẻgų telkimo būdus kariauną ir visuotinị liaudies šaukimą, kurių pagrindiniai uždaviniai yra skirtingi.

Pirmiausia apie Žemės kariuomenę. Žemès kariuomenė savo telkimo būdu yra tam tikra prasme demokratinè. Kiekvienas vyras, pajëgiantis pakelti ginklą, privalo dalyvauti kariniuose veiksmuose. Šios prievolès užuomazgų yra ir Jogailos 1387 m. privilegijoje. Sembai, skelbdami 1253 m. žygi prieš Klaipėdos pili, pranešè kiekvieną nestosiantị bausią mirtimi ${ }^{4}$ Tačiau visuotinio šaukimo kariuomenès žygiai ị kaimynines žemes yra išimtine retenybė, nes pagrindiné tokios kariuomenès užduotis - gynyba. Tolimi ir sunkūs žygiai pranoko kuklias daugumos laukininkų galias.

1 Jordan. O proischoždenii i diejanijach gietov. I., 1960, p. 136: “... post quos ripam Oceani item Aesti tenent, pacatum hominum genus omnino".

2 Scriptores rerum prussicarum. Leipzig, 1861. Bd. I (toliau - SRP), p. 733: “...Da ist sehrviel Krieg unter ihnen ..."

3 SRP, p. 52.

4 Eiliuotoji Livonijos kronika (toliau - ELK). Lietuvos istorijos instituto vertimas ị lietuvių kalbą; mašinraštis, p. 139. 
Kariauna buvo antra kariniu jęgų rūšis. Skyrėsi ir kariuomenès rūšiu pobūdis. Žemès kariuomenei buvo būdinga defenzyva, o kariaunai ofenzyva, nors užpultą kraštą gindavo ir kariaunos pajėgos. XIII a. pabaigoje prasidejjusiems lietuvių kariaunų žygiams, surengtiems ne vien i krikščionių kaimynų žemes, buvo skirta pakankamai dėmesio, nes kronikininkai apie juos paliko žinių. Ne visi jie buvo užfiksuoti, retas aprašytas išsamiau, tačiau pats ju gausumas nekelia abejonių. $1245 \mathrm{~m}$. popiežiaus pasiuntinys Jonas de Plano Carpinis, vykdamas per Lenkijos karalystès ir totorių žemes, nuolat jautė mirtiną lietuvių, kurie slaptai ir kiek galėdami dažnai užpuldinejjo pietų Rusiją, pavojų․ Kas gi ginė karingai nusiteikusius lietuvius ị tolimus kraštus? H.Paszkiewicziaus teigimu, lietuvių žygiai Rusijoje dažniausiai vykdavę palei upių, kurios būdavusios pagrindiniai prekybos keliai, tèkmę

Ne vien Rusia, bet faktiškai visos kaimyninès žemės nebuvo apsaugotos nuo lietuvių antpuolių.

Iš žygiu geografinių krypčiu ịvairovès galima daryti prielaidą, kad lietuvių žemių konfederacija, būdama ikivalstybinis darinys, neturèjusi politinès strategijos. Galime sakyti, kad tai lẻmė tikslų primityvumą. Viltis pralobti buvo pagrindinis akstinas leistis ị tolimus ir pavojingus žygius, todėl šiuos žygius vadiname grobio žygiais. Henriko Latvio liudijimu, lyviu ir latgalių kraštai lietuviams buvo maistas ir pašaras ${ }^{8}$. Be abejo, buvo grobiamas gyvas ir negyvas inventorius. Su užpultojo krašto gyventojais dažniausiai buvo elgiamasi taip: vyrai nužudomi, o moterys ir vaikai išvedami į nelaisvę 9 . Kito krašto vyras buvo suvokiamas kaip potencialus karys, todèl priešas, o kad tai nẻra išimtinis lietuvių bruožas, nesunku ịsitikinti $^{10}$. Mano manymu, šaltiniuose pasitaikantys duomenys apie dvasi-

\footnotetext{
${ }^{5}$ Łowmianski H.Studia nad dziejami Wielkiego Księstwa Litewskiego (toliau - Studia). Poznań, 1983 , p. 258.

6 “... Nichilominus tamen ibamus semper sub periculo capitis propter Lithuanos, qui saepe insultum faciebant occulte quantum poterant super terram Rusciae et maxime in locis illis per quos debebamus transire". - istorija, p. 160.

${ }^{7}$ Jagiellonowie ..., p. 28.

${ }^{8}$ HCL. p. 313: “... et erant Lyvones et Lethti cibus esca Lethonum”.

${ }^{9}$ HCL. p. 349: Lietuviai “... intrantes Saccalam, comprehendertunt viros multos et occidentes eos tulerunt omnem substanciam eorum, et mulieres et parvulos et pecora eorum rapientes secum abduxerunt".

${ }^{10}$ Plačiau apie tai žr.: Studia ..., p. 228-229.
}

8 
ninkų nužudymą taip pat remtų anksčiau minètą teigini: tvirtą vyro ir kario tapatinimo ịsišaknijimą. Tiesa, šiokį toki niuansą galètų duoti žemaičių dvasininkų, kaip nieko vertų dẻl to, kad jie nebuvo kariai, "herojinis" traktavimas ${ }^{11}$. Su tuo sutikti galime tik iš dalies, nepasiduodami kronikininkų sugestijai, kuriems dievo tarnų žūtis, gaubiama kankinystès aureolès, reiškia visai ką kita nei lietuviams. Suprantama, kad visuomenè, kuri egzistuoja kariškoje terpeje, labiausiai vertina karines vertybes. Neatsitiktinai Chrisburgo sutartyje minimi prūsų tulisonys ir ligašonys, šermenyse aukštinantys mirusiojo vagystes ir plěšimus, kuriuos jis atliko būdamas gyvas ${ }^{12}$. Pagal ši kontekstą keistai skamba M.Tumlerio mintis, kad po antrojo prūsų sukilimo išsirutuliojo draugiškesni kovos metodai ${ }^{13}$. Abiejų pusių daromi žiaurumai nesutrukdẻ priešą ịvertinti kaip karị. Antai Ragainès komtūras Liudvikas Libencelè, padaręs žemaičiams daug blogo, vis vien buvo jų gerbiamas ${ }^{14}$. Tokiu pavyzdžių yra ir daugiau. Žinoma, nèra taisyklès be išimties: vienas kitas kilmingasis buvo tarsi tikètinas išpirkos užstatas. Štai lyvių vyresnysis Uldevanas buvo išpirktas už žuvusio lietuvių vado galvą ${ }^{15}$. Panašiai buvo elgiamasi ir su lietuvių kilmingaisiais. I Livonijos vokiečių nelaisvę pakliuvęs Mindaugo seserẻnas Lengvenis buvo draugų (vrunde) išpirktas ${ }^{16}$. Ne visada būdavo apsaugotos nuo užpuolikų ịtūžio moterys ir vaikai. 1208 metais estus užpuolę latgaliai visus gyventojus žudė nepaisydami nei lyties, nei amžiaus ${ }^{17}$. Tačiau toles-

${ }^{11}$ Urban W.The Samogitian Crusade. Chicago. 1989. (toliau - The Samogitian), p. 20: "Consequently, the pagan nobles of Samogitia dealt with the representatives of christianity ruthlessly: the Ydelighted in burning churches and torturing priests ... They valued priests even less. Priests were useless for war, sex, or work; and they knew that some Teutonic Knights privately shared their attitude".

12 Pašuto V.T. Obrazovanije Litovskovo gosudarstva. M., 1959. (toliau - Obrazovanije), p. 500: “... Tulissones vel Ligaschones, homines videlilcet mendacissimos historiones, qui ... tormentorum infernalium promerentur, dicentes malum bonum et laudantes mortuos de suis furtis et spoliis, immundiciis et rapinis ac aliis peccatis, que, dum viverent, perpetrarunt" ...

${ }^{13}$ Der Deutsche Orden, von M.Tumler unter Mitarbeit von A. UDO. Marburg. 1981. p. 20: "Dabei entwickelten sich freundlichere Kampfmethoden".

${ }^{14}$ SRP. p. 159: “... frater Lodewicus de Libencele ... quantacunque mala fecit eis, tamen diligebunt eum ...”

${ }^{15}$ HCL. p. 351: “... et Uldewane secum deduxerunt. Pro cuius redemptione, postea datum est capuld eiusdem Lettonis occisi ..."

${ }^{16}$ Studija, p. 254.

${ }_{17}$ HCL, p. 309. 
nis pasakojimas verčia manyti, kad pirminis diferencijuotas elgimasis su užpultojo krašto gyventojais buvo nulemtas ne vien ūkinių interesų - juk "gyvasis inventorius" papildydavo nelaisvosios šeimos gretas, o gyvuliai bandas, bet ir papročių - kaip antai, vedybinių, kas etnologijoje vadinama vogtinėmis vestuvėmis ${ }^{18}$. Būtent šis aspektas yra perteikiamas H.Latvio žodžiais: "puellas quam plurimas, quibus solis parcere solent exercitus in terris istis"19.

Ne ką mažiau nei belaisviai ir gyvuliai lietuvius masino įvairiausias kitas turtas. Jo atkakliai buvo ieškoma sodybose, miškuose, net bažnyčios slenkstis nesudarydavęs kliūties ${ }^{20}$. Abatas Teodorikas, vyskupo Alberto pavedimu vykęs pas Polocko kunigaikštic, "prarado viską, ką su savim turèjo". Taisyklès "grobti - kas pagrobtina" įsigalejjimą galime nujausti iš to, kad lietuviai, žygiavę i Žiemgalą ir gavę skubią žinią apie pavojų savo kraštui, nuo Polocko pusès pasuko atgalios ir vis vien nesusilaikė neatėmę Rygos vyskupo žvejų rūbų ${ }^{21} .1226$ m. lietuvių kariuomenè, "kokios nebuvo nuo pat pasaulio pradžios”22, nusiaubẻ visą Toropeco sritị ir daug pirklių išmušè. Prekyba visur, taip pat ir Rytų bei Vidurio Europoje, dėl karinių priešiškumų nebuvo saugi ${ }^{23}$, tačiau niekad nesustojo, bet XIII a. pr. Lietuvai dar buvo toli net iki "prekybos karo ir taikos zonoje"25. Prekybos pajungimas karui aiškiai buvo matyti iš popiežių draudžiamo pre-

${ }^{18}$ Baldžius J., Vogtinès vestuvès.”Darbai ir dienos”, IX, K., 1940, žr. p. 66-75.

${ }^{19}$ HCL, p. 309.

${ }^{20}$ HCL. p. 296: "Lethones velocitate equorum deferuntur hac et illac circa ecclesiam et deo suos conservante ecclesiam non intrant, sed ad domum sacerdotis festinantes, equos et pecora rapiunt, vestes et cibaria et omnia, que inveniunt, vehiculis imponunt ... p. 297:” ... unus, ecclesiam intrans et ad equo suo non descendens nichilque ad rapiendum inveniens illos que in anguli latitantes ignorans, iterum festine recessit.... unus ex eis in vehiculo suo sedens, ecclesiam transeundo sacerdotes non vidit”, p. 313 ir kt.

21 HCL, p. 281. ir 268.

22 Polnoe sobranije ruskich lietopisei (toliau - PSRL), t. 1, 1927, p. 447-448.

23 PSRL. t. 15, p. 345-346.

${ }^{24}$ HCL, p. 340-341; “... ut et sibi colloquentes viam mercatoribus in Duna prepararent securum et pacem renovantes facilius Letonibus resistere queant ... et ibant cuemo mercatores in navibus.

suis, et induerunt se omnes armis suis, precaventes insidias Letonum ex omni parte Dune".

25 aliuzija ị: Mažeika R. Prekyba ir taika mirties zonoje // LKMA. V., 1993, t. 14, p. 105-118. 
kiu sąrašs ${ }^{26}$. Taip pat tuo požiūriu paminètini Livonijos pirklių skundai dèl juos apiplèšusių pskoviečių ar kitų rusų, kurie jų turtą perdavè lietuviams, turèdami tikslą, geriausiai perteiktą Livonijos magistro žodžiais: "propter quod dicti Lettwini, qui quasi viribus omnimo defecerant, infinita pecunia locupletati nunc longe validius quam hactenus fidem christianam impugnant"27.

Karo žygiai i gretimus kraštus buvo vienas pagrindinių nobilių turto šaltinių. Nepajungę laisvưjų bendruomenininkų darbo sau, jie grobdavo kaimyninių gyventojų turtą, tokiu būdu kompensuodami esamą trūkumą. Nors atskiros kariaunos paklusdavo teritorinių vienetų sudarytai taikai, tačiau visi valdymo reikalai buvo tvarkomi kilmingųjų, užtat taikos būdavo trumpalaikès. İ taiką žiūrima kaip ị apibrèžtą laiko tarpą, kai kariniai veiksmai nutraukiami. Ji suprantama kaip prekè, dèl kurios deramasi.

${ }^{26}$ Ten pat.

${ }^{27}$ Rowell S.C. Between Lithuania and Rus': Dovmont Timofey of Pskov, his life and cult (toliau - Between) // Oxford Slavonik Papers. New series XXV, 1992, p. 13. 


\section{Užuomazginiai mūšsiai}

Su grobio žygiu genetiškai yra susijusi XIII a. pr. lietuvių gentinė karyba. Dauguma Pabaltijo genčių buvo ịpratusios žygiuoti žiemos metu $^{1}$, kai šaltis žemę ir vandenis sukausto ledu, nes kitais metų laikais, kaip tvirtina Bartolomejus Anglas, šių kraštų užpulti neįmanoma ${ }^{2}$. Ateiviai iš Vokietijos, Livonijos kryžininkai, 1211-1212 m. ìsitikino, kad žiema yra tinkamiausias metas kariauti ${ }^{3}$, ir šio "sezoninio" veiksnio paprastai buvo paisoma visą lietuvių karų su kryžiuočiais laikotarpị.

Sékmingo grobio žygio laidas buvo jo netiketumas ir sparta. Isiveržusiems į Toreidos žemę lietuviams iš pradžių neblogai sekẻsi, nes kraštą jie užklupo neįspètą, o gyventojus su turtu - neišsislapsčiusius ${ }^{4}$. Turint grobị rankose, prasidėdavo antrasis žygio etapas - pasitraukimas. Tai buvę pavojingiausia. Pasklidus gandui apie užpuolimą, užpultieji visuotiniu papročiu kuo greičiausiai telkėsi priešą vyti arba vytis. Toks vaizdas savo ịprastumu ypač ryškus Rusijoje: lietuviai iš pradžiu plëšia rusų gyventojus, paskui traukiasi, o tada juos vejasi, tarkim, Naugardo ar Haličo kunigaikšču sutelktos pajègos. Paveja arba nepaveja. Nors 1217 ir 1223 metais naugardiečiai vijosi lietuvius, tačiau šie paspruko greičiausiai todél, kad nebuvo paėmę belaisvių, kurie visada suvaržydavo kariuomenès judèjimo greitị - metraščiai apie grobị tyli ${ }^{5}$. Užklupti grobiu aptekę lietuviai, traukiantys atgalios, dažnai neparodo didelio kovingumo. Jie yra linkę vengti mūšio, o kaunasi priversti kautis; taigi matyti aiškus siekis apiplešti, nužudyti beginklius žmones, bet vengti susidūrimo su priešininko kariais. Antai žiemgaliai, drauge su kalavijuočiais ịsiveržę i lietuvių žemes, pastebẻjo, kad gyventojai išsislapstę miškuose, ir vengdami gresiančios kovos tuojau pat susimete trauktis 6 .

1 HCL. “... circa quadragesimam, quando magis ille gentes suas exercere solent expeditiones", p.275.

${ }^{2}$ Bartholome-w the Englishman: “... therefore junneth that londe may be assailed in summer, but on wynter, when waters and ryvers ben yfrore” in, The Northern ..., p. 38.

${ }^{3}$ Urban W.The Baltic Crusade (toliau - The Baltic) Dekalb. 1975, p. 83.

${ }^{4}$ HCL. p. 296: “... invenienttes terram nullis rumoribus premunitam” ...

${ }^{5}$ PSRL. t. 10, p. 334.

${ }^{6}$ HCL. p. 304: "Et cecidit sors et Famam prevenisse et Lethones ad bellum paratos esse. Unde stupefacti Semigalli nimis, ad redeundum Thentonicos invitant eo quod Lethonum valde timeant insultum". 
Tenebūnie mūsų atidos aplenktas vienas svarbus momentas: kas su kuo kovoja. Minėtoji grobio žygio taktika nurodo, kad iš esmés susiduria karys su beginkliu. Kodẻl tai svarbu? Svarba, manyčiau, puikiai nusakyta F.Braudelio - "tikrovėje karas kaip menas buvo įmanomas tik tada, kai ji kariaudavo abi pusès" . Vadinasi, tokiu atveju, kai priešininkui nepripažịstama elementaraus gynimosi teisé, reikalas tampa paramilitariniu. Taigi patirtis, sukaupta tokioje kovoje, yra labiau medžioklinè nei karinè, o taip gal net būtų tinkamiau interpretuoti H.Latvio pasakojimą apie lietuvius "medžiotojus" ir rusus "kiškius". Patirtis yra karinè, kaupiama didžiausia kaina, kovoje karys prieš karị. Tad ties tuo ir apsistokime.

${ }^{7}$ Brodel F. Vriemia mira. t. 3. M., 1992, p. 53.

${ }^{8}$ HCL. p. 313: "Et fugerunt Rutheni per silvas et villas a facie Letonum licet paucorum, sicutfugiunt lepores ante faciem venatorum”. Žinoma, ši interpretacija neprieštarauja lietuvių dominavimo Livonijoje supratimui, plačiau žr. Dubonis A. Du šimtai pskoviečių saulès mūšyje (1236) // Lituanistica. 1990. Nr.1, p. 13-23. 


\section{Pėstininkų ir raiteliụ vaidmuo}

Manau, kad mūšiu analizès išeities taškas turi būti fakto, kas kaunasi - raiteliai ar pėstininkai, - nustatymas, nes skirtingų laikotarpių, tarkim, 1208 m. ir Žalgirio, - mūšių kontempliavimas toje pačioje paradigmoje nèra įtikinamas ${ }^{1}$. Šio straipsnio perspektyvinis analizės fonas, padedantis ivvertinti, bet ne niveliacijos pamatas, yra klasikinè viduramžiu Europos raitelių taktika - sunkiai ginkluotų riterių ataka². Mano galva, tai perprasti ir reflektuoti yra būtina. To neivertinimo padarinys keista interpretacija, pasitaikanti, pvz., R.Batūros ar A.Kirpičnikovo darbuose, implikuojanti kokybinị 13 a. Lietuvos ar Rusios pèstininkų lygiavertiškumą XIV a. Flandrijos ar Šveicarijos pėstiesiems kariams ${ }^{3}$.

Iš Petro Dusburgiečio pasakojimo apie prūsus galima daryti išvadą, kad tarp jų kariu pėstininkų ir raitelių santykis buvo 10 su 14. Šis santykis ganètinai tikètinas žinant, kad raitelis iš esmès siejamas su kilminguoju. Tačiau ši išvada jokiu būdu nèra išsamus atsakymas ị klausimą. Juk, kaip minèta, į tolimus grobio žygius leisdavusios kilmingụjų kariaunos ir šie kariai jodavę raiti. Tad kaip jie kovodavo susidūrę su ginkluotu priešininku? Būdami priversti kovoti ir iš anksto pastebeję priešą, jie pasi-

${ }^{1}$ žr.Batūra R. Lietuviškos taktikos reikšmė Žalgirio mūšyje (toliau - Lietuviškos taktikos)//

Acta Historica Universitatis Klaipedensis. Nr. 1. V., 1993, p. 65-77.

${ }^{2}$ Keen M.Chivalry (toliau - Chivalry), London. 1984. p. 23: "It would seem, however, that it was not until the eleventh century that as a result of further technical advances, the tactic developed whereby, at a crucial point in battle, the charge of heavy cavalrymen holding their lances in the "couched" position (tucked firmly under the right armpit and levelled at the enemy) could decide the day ... which was to be long the classic cavalry tactic of medieval warfare".

${ }^{3}$ Lietuvių karas su kryžiuočiais (toliau - LKK). V., 1964, žr. p. 87: "Lietuvos pėstininkų vaidmuo kovoje buvo kitoks, negu Vakarų Europoje. X - XIII a. Vakarų Europos feodalinèje kariuomeneje péstininkai nesiskaitė kariais, jie daugiausiai saugodavo riterių kariuomenès stovyklą ir beveik nedalyvaudavo kautynèse. Tik nuo XIII - XIV a. pradžios Flandrijoje, Šveicarijoje, Anglijoje, Prancūzijoje pèstieji - o jais buvo miestiečiai bei laisvieji valstiečiai vis plačiau ima dalyvauti kare. Palaipsniui išryškejja nepaprastai didelis pėstininkų vaidmuo kare. Tuo tarpu Lietuvoje, panašiai kaip Rusijoje, šalia raitelių svarbų vaidmenį kovojant su kryžiuočiais visą XIII a. ir vẻliau vaidino pėstieji. // panašiai ir p. 7: Kirpičnikov A.N. Voennoe dielo na Rusi v XIII - XV veke. M., 1976.

4 SRP, p.52.

14 
renka gynybinę taktiką. Jeigu laikas ir aplinkybès palankios - apsikerta mišku, kaip antai Lengvenio vedami kariai, įspėti Pinsko kunigaikščio Michailo, atsivejančių haličènų laukè miške apsikirtę ${ }^{5}$.

Karybos istorikas H.Delbrukas tvirtina, kad "raiteliai pajègūs tik puolamiesiems veiksmams, jie nežino apie jokią gynybą"6. Iš tiesų sunku įsivaizduoti raitelių kautynes, kai juos skiria medžių užtvaros. Todẻl čia susiduriama su gan dažnu reiškiniu - karių nulipimu nuo žirgų7. Šis reiškinys minimas neretai, ir net riteriams nebuvęs svetimas. Vargu ar Vaišniaus Ruškaičio būrio karių kritimą nuo arklių galime traktuoti kaip jų nemokẻjimą joti, bet greičiau kaip bandymą gintis pėstiems ${ }^{8}$. Negalėdami priešpriešiais pastatyti lygiavertės raitelių rikiuotès, lietuviai nulipdami nuo arklių medžių užtvaras ar kitas gamtines kliūtis naudojo kaip priemones, efektingai mažinančias ị akis krentantị raitelio pranašumą prieš péstininkus, pavyzdžiui, priversti riterius kautis pésčius, kas buvo pasiekta Karusos mūšyje, kai riterių žirgai, įsipainioję i r rogių užtvarą, buvo išbadyti ${ }^{9}$.Tuo buvo tikimasi suardyti priešininko rikiuotę ir jam primesti kovos sąlygas, kuriomis organizuota karinė jẻga negali pasireikšti, o viską lemia kiekybine persvara ir gaivališka kova vyras prieš vyrą. Saulès mūšyje, nors lietuviai ir privertẻ kryžiuočius kautis "jiems patiems visai nenorint, tačiau kaip paskutinès priemonès palaužti riterių pasipriešinimą griebėsi taranų"10. Ši taktika, kaip matome, ne visada nepasiteisinda$v^{11}$. Regis, neatsitiktinai metraščiai mini didesnius rusų patirtus nuostolius netvarkingose kovose: siaubiant apylinkes, įsiveržiant ị tuščią Pskovą, kaunantis Staraja Rusoje ar ịpuolus i Toržoką ${ }^{12}$. Čia ir slypi Haličo kunigaikščio Danieliaus įžvalgių žodžių, kuriais jis perspejjo savo karius, pras-

${ }^{5}$ PSRL. t. 2, p. 182.

${ }^{6}$ Delbriuk G. Istorija voiennovo iskustva v ramkach političeskoi istorii. t. 3. M., 1933, p. 167.

${ }^{7}$ A.Nikžentaitis tokią išvadą pagrindžia remdamasis Eiliuotają Livonijos kronika. Žr. Nikžentaitis A. XIII - XV a. Lietuvių kariuomenès bruožai (toliau - kariuomenès bruožai) // Karo archyvas Nr. 13, p. 3-34, p. 8. V., 1992.

${ }^{8}$ PSRL. t. 2, p. 181-182.

${ }^{9}$ ELK, p. 287: "Kai arti visai jie puole /Iš jų būrio pirmesnieji /İsivèlè tarpe rogių/ Tai lietuviams labai tiko/ Jie išbade jųjų žirgus/ Žymesnioji dalis brolių/ krito mūšio sūkuryje ...”

${ }^{10}$ ELK, p. 70.

${ }^{11}$ PSRL. t. 4, p. 202: “... i bišasia s Litvoi, sgoniša Roušan’ s kon' i mnogo konev otjaša i oubiša Dožamira Torpinič, a Roušan' mnogo i razgoniša ich po lesu”. PSRL. t. 3, p. 54: “... i bišasia s nimi (su lietuviais), i otjaša u Novotoržcev koni i samich biša i poidoša s polonom proče”.

12 PSRL. t. 3. p. 32, t. 4, p. 214, t. 7, p. 162. 
mè: 'Krestijanam prostranstvo jest' krepost, pokanym že jest' tiesnota: dierjaždje obyčaj jest na bran"13.

Kalbėti apie rikiuotę, sunkiai atskiriamą nuo minios, yra keblu. Lietuvių ir kitų baltų kariuomenėms ar karių sambūriams pavadinti rašytiniai šaltiniai vartoja ịvairius terminus: exercitus, potencia, acies, cuneus, turma, turba, polk ir pan. Terminai ne visada pakankamai informatyvūs, mat dažnai tas pats žodis taikomas skirtingiems dariniams apibūdinti, kaip antai: Žvelgaičio kariuomenè sustojo i pleištą (cuneus) ${ }^{14}$ ir Vytautas prieš Žalgirio mūši karius surikiavo ị pleištus ir pulkus (turmas) ${ }^{15}$, tačiau pirmuoju atveju kariai buvo pėstininkai, antruoju - raiteliai. Tas pats karių pulkas viename sakinyje gali būti pavadintas "turma", o kitame - "turba" (minia) ${ }^{16}$. Dèl šių priežasčių mėginant apibrèžti rikiuotę, suprantant ją kaip darinị, igalinantị sujungti atskirų kovotojų jëgas, verta išskirti du momentus: kodẻl kariuomené dalijama ị atskirus dalinius ir koks rikiuotès efektyvumas mūšyje. Grobio žygio metu kariuomené žygiuodavo pasidalijusi į dvi dalis, tarp kurių būdavo vedami belaisviai ${ }^{17}$. Krašto grobimo metu skirstomasi į daugelị būrių, kurie pasklidę apylinkèse grobdavo, o vèliau susirinkdavo iš anksto numatytoje vietoje.

${ }^{13}$ PSRL. t. 2. p. 186.

${ }^{14}$ HCL. p. 276-277: "Venienttes ergo Lethones cum tota preda et captivis, qui millenarium suoerabant numerum, exercitum suum dividunt in duas partes et, in medio captivos constituentes propter nimiam profunditatem nivis per unam tantum viam singuli gradiuntur. Sed mox ut primi eorum vestigia precedencium reperiunt, insidias suspicantes subsistunt,et ita postremi cum captivis primos insequuti in unum colliguntur cuneum” (pabr. mano).

${ }^{15}$ Ašcik K. O szyku bojowym bałtow (toliau - Oszyku). //Studia i materiały do historii wojskovošci (SMHW). 1970. T. 16, p. 3-10. Žr. p. 6 cit. Joannis Długosii Opera omnia, 1877. T. XIII, p. 19, 20: “...Alexander autem Dux Magnus Lithuaniae die illo Lithuanicum ordinat exercitum, et dividens illum vetusto patriae per cuneos et turmas in quolibet cuneo milites in equis humilioribus, aut parum bene armis vestitos in medio constituit, quos alli in equita potiori, et insigniter armati includebant. Cunei autem huiusmode pressi et glomerati ordinum raritatem abhorrebent: unus tamen cuneus ab altero per late patens ac distinctum, spatium tendebatur. Hos tandem cuneos Alexsander Dux Magnus Lithuaniae quadraginta signis, quae banderia vocitamus, attribuit, et singulas quasque cohortes et turmas sequi signa et parere suis ducibus iussit”.

${ }^{16}$ SRP, p. 170: “... diviserunt se in duas turmas ... Reliqua turba infidelium evasit”.

17 Žr. išn. 14 ir HCL, p. 351. 
Tai buvo žygio patogumas ${ }^{18}$, ne taktikos sumetimas. Ties antruoju momentu apsistokime plačiau.

Kita išskirtina gynybinio mūšio lytis - ginkluotų priešininkų tiesioginis susidūrimas. Lietuviai, pastebejję, kad atsiveja kunigaikščio Jaroslavo kariai, ties ežeru išsirikiuoja - "ispolčišasia" - ir kovodami prie ežero pralaimi ${ }^{19}$. Tačiau lieka neaišku, kas kovèsi - ar raiteliai, ar pėstininkai. Panašus mūšis, vykęs prie Nevelio, mums gali būti šios mįslès įminimas. Čia pasakoma, kad lietuviai "susèdo (pabraukta mano) savo ịpročiu i tris eiles už skydụ” (...siedoša ve tri riady za ščity po svojemu norovu ${ }^{20}$. Śiuo konkrečiu atveju H.Łowianskio pasakymas, kad ị tokią falangą stodavosi lietuvių raitija, nėra visiškai tikslus ${ }^{21}$. Remdamiesi K.Ašciko tyrinèjimais, įvairių laikotarpių šaltinių apie lietuvių bei kitų baltų nuo seno naudotą pleišto rikiuotę liudijimais, galime tvirtinti, kad ir ši "skydų tvirtovè" buvo surikiuota išorejje pastatant geriau, o viduje blogiau ginkluotus karius $^{22}$, išilginė rikiuote "en haye" 23 , kartais naudota Vakarų Europos riterių, visai neįtiketina. Dabar negaliu remti vieno spejjimo, ar tokia rikiuotè būdavusi plokščia, ar ì priekị smailejjanti. Svarbu tai, kad ana "skydụ tvirtovè" 24 buvo pèstininkų rikiuotè, be to, ir mažai manevringa: jos ịsibègèjimo distancija, jei tokia buvusi iš viso, buvo nedidelè. Pradèję kautynes prie ežero, kariai jas ir baigdavo ties juo arba jame tiek mūšyje su Jaroslavo kariais, tiek prie Nevelio. Apsisaugojimas nuo apsupimo užnugaryje palikta gamtine kliūtimi yra ženklas, kad karys drịsta kautis su kariu tiesiogiai; todèl čia galime neabejotinai įžvelgti rikiuotẻs užuomazgą. Vaizdžiau tariant, tai - pirmas dar nedrąsus išejimas ị sceną. Šio pleiš-

${ }^{18}$ SRP. p. 158: "Notandum, quod quando movetur bellum, exercitus dividitur in diversas vias, ut possit ordinate et sine pressura procedere".

${ }^{19}$ PSRL. t. 15, p. 345-346: “... ispolčišasia protivu jemu pri jezeja ... i bišasia s nimina ozere”...

${ }^{20}$ PSRL. t. 2, p. 200.

${ }^{21}$ Studia. p. 347: "W tego rodzaju falangę ustawiała się jazda litewska,atakowana przez wroga, natomiast występując zaczepnie, usiłowała osaczyc zewsząd przeciwnika i z roznych stron uderzała raz po raz w jego szeregi”.

22 Žr. O szyku p. 5. Gudavičiaus E. Lietuvių pašauktinès kariuomenès organizacijos bruožai (toliau - pašauktinès bruožai) // Karo archyvas Nr. 3. p. 43-48, V., 1992.

${ }^{23}$ Ekdahl S. Jono Dlugošo "Prūsų vẻliavos" Žalgirio mūšio šaltinis (toliau - "Prūsų vẻliavos"). V., 1992. p. 21.

${ }^{24}$ Drevnieanglijskaja poezija. M., 1982. žr. Brunanburgo mūšio apdainavimą, p. 133-137 ir p. 305-306. 
to, į kuri įsirèžusio priešo rikiuotè turi suskilti, o ne jis pats ją suskaldyti, paskirtis geriau išryškès palietus raitelių vaidmenị kautynėse.

600 lietuvių, matydami jų link artėjančią vokiečių ir latgalių kariuomenę, pasiruošè mūšiui, o 200 geriausių raitelių pastatė nuošaly, kad jie persekiotų bėgančius priešus ${ }^{25}$. Persekioti neteko, nes susikovus siaurame kelyje lietuviai buvo išblaškyti. Teutonai grobio paėmė apie 400 arklių, todèl, matyt, ta karių dalis, kuri tikejjosi įveiksianti priešininkus, buvo nulipusi nuo arklių, beje, tarp jų kovèsi ir žuvo vadas. Arklių nenaudojimas mūšyje rodo, kad jų paskirtis visų pirma transportinè. Prūsų nobilis Mata maršalui Henrikui prieš Durbès mūši pataria palikti arklius toli nuo savęs, kad liaudis narsiau kovotų, neturẻdama vilties raita pasprukti iš mūšio lauko ${ }^{26}$. Panašiu būdu žirgas pagelbedavo ne tik šio pasaulio pavojuose, tačiau ir po mirties raiteli gabendamas ị anapusini pasaulį ${ }^{27}$. Nesunku numanyti, kad, neturint raitelių kovos ịgūdžių, žirgo ir raitelio amžinas išsiskyrimas nėra sudėtingas, o prisimenant dar Vulfstano minètą žirgų brangumą, darosi aišku, jog tokia rizika buvo labai nepageidautina. Todėl lietuviai kartais ne tik save, bet ir žirgus apkirsdavo medžių užtvaromis ${ }^{28}$. Didesnio lietuvių kovingumo, kai jie atsiduria užpultụjų vietoje, galime tikètis vien dẻl gimtųjų namų gynimo instinkto. Sia prasme įdomus $1208 \mathrm{~m}$. žiemgalių ir vokiečių mūšis su lietuviais, kuris tyrinètojų yra dažnai paliečiamas ir gan skirtingai interpretuojamas ${ }^{29}$.

Besitraukiančios kariuomenès persekiojimas paneigia apgaulingo pasitraukimo, siekiant suardyti užpuolikų rikiuotės gretas, galimybę. Ne-

${ }^{25}$ HCL. p. 412-413: “ Lettones quoque, videntes eos ad se venientes, ordinant exercitum suum ex adverso et ducentos ex melioribus equitibus suis seorsim statuentes, ut ipsi persequantur Theuthonicos fugientes. Ceteri omnes in magna turba veniunt obviam theutonicis “...

${ }^{26}$ SRP. p. 96: "nobilis dictus Matto, ... ait: relinquamus equos nostros longe a nobis, ut non sit nobis spes redeundi ad eos, et accedamus pedestres ad ipsos, sicque populus destinatus auxilio equorum, manebit in prelio, aliter in fugam sine dubio convertetur".

${ }^{27}$ Obrazovanije. Christburgo taikos sutarties ištrauka:”... mendaciter asserunt se videre presentem defunctum per medium celi volantem in equo, armis fulgentibus decoretum, nisum in manu ferentem et cum comitatu magno in aliud seculum procedentem ...”, p. 500.

${ }^{28}$ ELK, p. 359.

${ }^{29}$ plg. Lietuviškos taktikos p. 68 ir Gudavičiaus E.Kelios pastabos apie lietuvių taktiką Žalgirio mūšyje (toliau - Kelios pastabos) // Karo archyvas. Nr. 13, p. 34-43. V., 1992. 
abejojama lietuvių raitelių vikrumu bei miklumu, iš ịvairių pusių apmètant priešą svaidomosiomis ietimis ir piemenų lazdomis ${ }^{30}$. Tai rodo, kad raiteliai nesueina ic artimas kautynes ${ }^{31}$. Pavieni, nerikiuotini veikimą galime ryškiau įsivaizduoti iš H.Latvio kalbos apie fryzą Vigboldą, kuris tai pabėgdamas, tai grị̌zdamas (... modo fugiendo, modo ad inimicos redeundo ... $)^{32}$ trukdo vokiečius puolantiems priešams. Galiu pateikti dar vieną pavyzdi, kuris tinkamai parodo dvi gentinès raitelių kariuomenės funkcijas: vokiečių riteriams vejantis estus, lyviai ir letai joja paskui, kad matydami mūšio baigti arba persekiotų sumuštuosius, arba pabėgtų ${ }^{33}$. Taigi ryškejja dar vienas raitelių veikimo laukas, ne tiek tikrame mūšyje, kiek jo baigiamosiose fazèse - persekiojimo, kur raitas karys vis dèlto nebuvo vienvaldis.

Lietuvių kariai, suvokdami savo aiškią kiekybinę persvarą, nebijo pulti iš Jersikos bėgančių riterių ir puldami iš užnugario nukauna visus tris $^{34}$. Manytina, jog P.Dusburgiečio Durbès mūšio aprašymas, neva 3-4 priešai nukaudavę 100 krikščionių, pabrěžia būtent tą faktą, kad dažnai didžiausi nuostoliai būdavo vieniems bėgant, kitiems vejantis. Ivveikti priešą, atsisukusị veidu, buvo daug sunkesnis uždavinys, tam vien noro neužtenka. Paimto ị nelaisvę Lengvenio brolis priešininkus puola vytis stačia galva ir, nors garbingai, bet krenta.

Daumanto kariams nusiaubus Gerdenio valdas, pastarasis vejasi, tačiau, pakliuvęs į pasalas, patiria pralaimejjimą ${ }^{36}$. Puolimas iš pasalų dažnai buvo praktikuojamas tiek prūsų, tiek lietuvių. Jam pavykus, laimėto-

${ }^{30}$ HCL. p. 305.: "Quod intelligentes Lethones, velocitate equorum suorum eos undique circumvolant et, prout consuetudo eorum habet, circumferentur hac et illac, modo fugiendo, modo persequendo, et lancearum suorum ac pedorum missione plures vulnerant”.

31 Žr. Kelios pastabos, p. 35.

${ }^{32}$ HCL, p. 323.

${ }^{33}$ HCL, p. 322: “... ordinantes tamen in prima acie Theuthonicos, ut ipsi post tergum sequentes et belli exitum considerantes, sive ad persequendam sive ad fugiendam sint paratiores.

${ }^{34}$ HCL. p. 358: “... alii cum Lettis per viam redeuntes, a Letonibus post tergum impugnantur, et videntes Letti suorum paucitatem in fugam convertuntur. Et pugnantes milites, Meynardus, logannes et Jordanus, et non valentes tanto exercitui resistere, ceciderunt tandem interfecti ab eis".

${ }^{35}$ ELK, p. III.

${ }^{36}$ PSRP. t. 3, p. 59. 
ju labai greitai tampa puolantysis - toks mūšis tartum akimirka. Kovos ilgumas priklausydavęs nuo sąlygų panašumo. Kai nėra rikiuotès, kaunasi iki nuvargimo ${ }^{37}$, rikiuote, veikdama iš vienos pusès, priešininką palaužia netrukdoma, rikiuočių susidūrimas - pergalès lenkimas ị vieną ar i kitą pusę, pasak Livonijos eiliuotosios kronikos, "kas kovoj ištverti gali, daro priešams tamsią dieną" ${ }^{38}$. Lietuvių raitelị visų pirma apibūdinę kaip raitą pėstininką, turime pasakyti, kad iš trijų pagrindinių raitelio funkcijų - pralaužiamosios jẻgos mūšyje, žvalgybinès ir transportinès ${ }^{39}$ - įvaldyta tik pastaroji. Konstatuodamas, kad péstininkų rikiuotė atsirado anksčiau, manau, jog ilgainiui ji buvo perimta raitelių. Ši procesą galima pavadinti taip: raitas pėstininkas tampa raiteliu. Visai tikètina, kad pleišto sudèties kitimo laikotarpiu galejo būti ir pésčiųjų, ir raitelių. Lielvardès ir Aizkrauklès mūšių eiga ${ }^{40}$ leistų manyti, kad lietuvių pusèj kautasi ir raitelių. Ši problema anaiptol nėra išgvildenta.

37 HCL. p. 273: “... militibus advenientibus de civitate, iuxta Montem Antiquum cum paganis pugnam ineunt et bello invalescente eo usque preliantur, donec fessi ad invicem separantur žr. Prūsijos žemès kronika (toliau - PŽK). V., 1985, p. 181.

38 ELK, p. 112.

39 Wilinski K. Walki polsko - pruskie w X -XIII w. (toliau -Walki). Łódz, 1984, p. 7.

40. ELK, p. 221-222 ir 305-310. 


\section{Gentinio kariavimo ypatybės}

Negalima neskirti dėmesio įrankiams, kuriais kovojama. Turimas arsenalas išoriškai geriausiai parodo konfliktuojančiu pusių lygị. Jo reljefiškumą galime nustatyti sugretindami baltų ir kryžiuočiu ginkluotę.

Yra žinoma, kad visos Pabaltijo gentys didesniam savo saugumui užtikrinti šalia natūralių kliūčiu yra turejjusios ir medines pilis. Tai patvirtina gausūs šiuose kraštuose piliakalniai. Vis dèlto vyskupas Meinhardas lyvius apkaltino paikumu, nes pastarieji neturëję, jo supratimu, jokių tvirtovių, ir pažadejjo jiems pastatysiąs mūro pili, jei šie priimsią krikštą ${ }^{1}$. Ikškileje pastatyta mūrinè pilis šiame krašte buvo daugiau negu naujovè, o anekdotinis pasakojimas apie žiemgalių ketinimą virvėmis nutraukti ją i Dauguvą yra labai iškalbingas ${ }^{2}$. Apskritai viduramžiais imti pilis nebuvo lengva jokiai kariuomenei. Todèl vokiečiams Pabaltijyje panaudojus iki tol čia net nežinotus pristumiamuosius bokštus ir akmenų svaidykles, atkakliai ginamą pili užimti dažnai būdavę sunku. Užimti kryžiuočių pili dar sunkiau sekęsis jų priešams. Net Traidenio kariuomené, dieną naktị puldama Daugpilio pili su keturiomis "gana didelèmis" akmenų svaidyklèmis, nepasiekia tikslo, o kariai nudžiunga gavę komandą trauktis ${ }^{3}$. Nusižiūrèjimo ir kopijų neužtenka įvaldyti iš pirmo žvilgsnio net nesudètingai technikai, kuri dažniausiai buvo gaminama vietoje, o pasitraukiant sudeginama. Rusai, puldami Holmo pilaitę, vokiečiu pavyzdžiu padaro nedidelę svaidyklę, bet ja sužeidžia nemažai saviškiự ${ }^{4}$ Vèluvos apgulimo metu kryžiuočiams sužeidus akmensvaidès meistrą, lietuvių kariuomenė sutrinka ${ }^{5}$. Vytenio kariuomenè, 17 dienų atkakliai puldinëjusi Kristme-

${ }^{1}$ HCL. p. 259-260:”...causatur iam dictus Meynardus Lyvonum stulticiam, eo quod municiones nullas habeant, quibus castra fieri pollicetur, si filli dei censeri et esse decreverint”. Kroninkai Galas ir Kadlubekas taip pat teige, kad prūsai ir jotvingiai išvis pilių neturèję. Žr. Studia p. 330 .

${ }^{2}$ Livonijos kronikos (toliau - Livonijos), V., 1991, p. 25.

${ }^{3}$ ELK, p. 300.

${ }^{4}$ HCL, p. 289: "Fecerunt eciam Rutheni mechinam parvam more Theutonicorum, sel nescientes artem lapides iactandi, plures ex suis post tergum iactantes leserunt.

${ }^{5}$ SRP, p. 112: “... sed Henricus predictus quendam virm nobilem et potentem capitaneum Lethowinorum, cum balista sagittans telo tetigit et occidit, et ex alia parte quendam magistrum, qui ad raparacionem mechine ascendit summitatem ejus, sagitavit, et cum telo affixit manum ejus ad mechinam, quo viso infideles territi ab absessione recesserunt". 
melio pili su dviem apgulos mašinomis, galiausiai ryžtasi senoviniam pilies padegimo metodui, prinešant prie pilies šiaudų, stagarų ir malkų Paprastai tiesioginis puolimas kainuodavęs daug, ypač puolančiajai pusei, todèl pats paprasčiausias pilies èmimas XIII a. buvo iš pasalų ir kiečiausio rytmetinio įmygio metu ${ }^{7}$.

Puolimą su apgulos mašinomis lietuviai buvo daugiau ar mažiau beịvaldą, o tiesiaeige pilies ataka - ką kartais sau leisdavo Ordino vadovybè, kaip antai: puolant Gardino pilị, tinkamose vietose išdèstyti šauliai dengè puolejus, kurie ị sienas atrèmę kopéčias veržèsi vidun ${ }^{8}$, - pranoko jų galimybes. Dažnai kryžiuočių pilys, ypač prūsų sukilimų metu, būdavo blokuojamos, kad nuo bado išsekusi igula pasiduotų.

Nebuvo bereikšmis dalykas ir karių ginkluotès nepakankamumas. Gerai apsišarvavusių kryžininkų, kopiančių ị Pieštvės pilies sienas, pilènai negalejjo sulaikyti nei ietimis, nei kalavijais, nei kitais kokiais ginklais, todèl pagriebę mietus rèmé kopiantiesiems į krūtines ar nugaras ir tokiu būdu stūmé nuo sienų ${ }^{9}$ Ginklų rūšių ịvairove baltai nedaug atsiliko nuo vokiečių. Tačiau brangius ginklus, tokius kaip kalavijas, šalmas ir šarvai, teturejjo elitine karių viršūnè, kuri buvusi negausi ${ }^{10}$. Šiame straipsnyje jojamasis gyvulys sinonimiškai buvo vadintas "arkliu” ir "žirgu”, tačiau faktiškai lietuvių žirgas, kad ir ištvermingasis žemaitukas, palyginti su riterio žirgu, kuris galejjo būti pusantro karto didesnis, tebuvo arklys. Žirgų klausimas Lietuvoje buvo opus ir XIV-XV a. ${ }^{11}$

Dauguma baltų karių buvo ginkluoti ietimis ir skydais. Tokie lengvai ginkluoti kariai, sunkiai ginkluotų riterių ịvertinimu, buvo beginkliai, pvz., H.Latvis apibūdina lyvius kaip gentị, neturinčią šarvų ${ }^{12}$, todèl rite-

${ }^{6}$ SRP, p. 181-182.

${ }^{7}$ SRP, p. 134: skalviai "navigio venientes ad castrum fratrum Labegowe improvise in ortu diei quiescentibus adhuc hominibus in stratu suo, ipsum expugnaverunt ...”, p. 190:”... improvise intraverunt in ortui diei suburbium castri Gedemini, et incendio destruxerunt ..."

${ }^{8}$ SRP, p. 147:"...et dum transivisset Memelam, ordinavit sagitarios ad loca debita, applicatisque scalis ad menia $\mathrm{t}$ am grande bellum ortum fuit inter eos, quod formidolosi talia inscipere non auderent".

${ }^{9}$ SRP, p.186:"...castrenses nec gladiis, nec aliquo genere armorum poterant ipsos ab ascensu prohibere. Tandem duo vel tres aut plures accepta hasta posuerunt eam ad pectus vel dorsum ascendencium, et sic premendo eos a mennis dejecerunt".

${ }^{10}$ Pašauktinès bruožai, p. 47-49.

${ }^{11}$ Kariuomenès bruožai, p. 6-10. ir 18-20.

${ }^{12}$ Livpnokps. p. 35, ir HCL, p. 272. 
riams atvirame mūšyje jie nebuvo didelẻ kliūtis, antai estus “... sumyniojo kaip žolę / Lyg beginkliai būtų buvę"13. Apie liaudies karių ginkluotės tobulèjimą vargu ar galima kalbėti, nes jų ginklų specializacija niekad netapo išskirtinai karine: įrankiai, naudojami medžioklèje, ūkyje ar krašto gynybai, iš esmès buvo tie patys. Šių karių sugebejjimas panaudoti tokius daiktus, kaip antai akmenis, taip pat nepamirštinas ${ }^{14}$.

Ipatijaus metraštyje, kur aprašyta kova prie Vorutos pilies, kaip savybingiausi atskirų tautų ginklai minimi: vokiečiu - arbaletai, polovcų lankai ir strèlès, o jotvingių - ietys ${ }^{15}$. Galime sakyti, kad ietis - baltų ginklas, par excellence. Kaip taikliai pasake E.Gudavičius, "baltai svaido ietis ten, kur kitos tautos šaudo strẻlėmis"16. Baltu turèti lankai tiko medžioklei, bet sunkiai tiko karui. Lietuviai dar ir XIV a. sunkiai verčiasi be rusų šaulių pagalbos. Regis, tik apie XIV a. vid. lietuviai lanką ima naudoti karinèms reikmėms ${ }^{17}$. Ribotą lanko panaudojimą sąlygojo keletas veiksnių. Prisiminkime Danieliaus žodžius apie pagonių įprotị kovoti tankumynuose ir minioje, kur nèra erdvès lanko šūviui. Čia norèčiau atkreipti dėmesi i i tai, kad stepių kariai totoriai prieš puldami laidydavo ị priešą debesis strèlių ir vien šis skirtumas yra argumentas, paneigiantis nuomonę apie totoriškos taktikos perimamumą. Antra vertus, rikiuotès ir atskirų taktinių dalinių užuomazginẻ būklẻ sunkiai leidžia tikėtis kovinių veiksmų darnos. Juk matėme, kad net raitelių ir pėstininkų vaidmenys XIII a. pr. vienas nuo kito gana nutolę. Vyraujanti lietuvių gynybinė mūšio taktika lėmẻ didžiulę svarbą skydo, kuris buvo sẻkmingai patobulintas sukuriant lietuviško tipo skydus, 14-15 a. paplitusius Rytų ir Vidurio Europoje ${ }^{18}$. O juk šaudant iš lanko skydas ganètinai trukdo. Kuršių iš

${ }^{13}$ ELK, p.42.

${ }^{14}$ Chronicon seu Annales Wigandi Marburgensis (toliau - Wigandi); ed J.Voigt et E.Raczynski, Poznaniae, 1842 p. 215; "Sed et pagani celeriter in eos injiciunt lanceas, petras, kambucas, letaliter vulnerando, non obstantibus galeis aut loricis etc."

15 PSRL. t. 2, p.187.

${ }^{16}$ Pašauktinès bruožai, p. 49.

${ }^{17}$ Wigandi, p. 104: “...contra castrum Welun... in qua pugna socius marschalci, cognomine de Grunenberg fuit telo interfectus...”, p. 161; “...pecora transfigunt telis et...eqios educentes..."

${ }^{18}$ Ascikas K. Liketuviškas skydų tipas//Mokslas ir gyvenimas. 1978. Nr. 12, p. 26. 
dviejų lentų padaryti skydai, nešami prilaikant piemenų lazdomis, taip varžo judesius, kad net trukdo nešant malkas ${ }^{19}$. Minimi techniniai ir organizaciniai lanko naudojimo sunkumai dar būdingesni arbaletui. Šis sudètingesnis ginklas savo kovinėmis ypatybèmis pralenkẻ lanką tiek šaudymo atstumu, tiek pramušamaja jëga. Vokiečių arbaleto ịvaldymo pranašumas buvo bene pats skaudžiausias jų priešininkams, o šita paslaptis būdavo slepiama. Žiemgaliai, paèmę Tèrvetę, vieno ị nelaisvę pakliuvusio vokiečio buvo mokomi juo šaudyti ${ }^{20}$, tačiau tai nepadarè perversmo ju karyboje. Kad lanką, kaip ir arbaletą, buvo sunku įvaldyti taip pat ir dèl prietarų, galime ịsitikinti iš to fakto, jog po pirmos nelaimingos pažinties su arbaletu, kai vienas prūsas, nežinodamas, koks čia daiktas, netyčia nusišovè, visi prūsai èmè šio ginklo labai bijoti ${ }^{21}$. Iškèlę klausimą, ar negalèjo prūsai išsigąsti, o jei išsigando, tai kodèl, pereikime prie trapiausios - ideologinès - srities aptarimo.

Istorikams nėra duota galimybė persikelti ị kitą laiką ir tyrinëjamos epochos žmonių klausti "kodèl” bei išgirsti atsakymą "todèl, kad ..." Vis dèlto žmonių pažinimo intencija skatina spèti vyraujantị epochos klimatą.

Ketindami suvokti gentinę karybą grynuoju pavidalu, užmirškime tikètinus Pabaltijo genčių skirtumus, idant aptikę bendruosius principus lokalizuotumėme išeities tašką. Didžiają XIII a. pr. karų dali sudarė virtinè atsitiktinumų - pasalos, netikèti antpuoliai, grobimai. Nusistovèjusių karinių taisyklių nebuvimas gimdė nežinią, kurios neatsiejamas palydovas yra magija. Tradicinès visuomenès visas gyvenimo sritis persmelkianti magine pasaulejjauta karą glaudžiai siejo su kasdienybe. Jo ịprastumą lẻmé ne tik taikos kaip paliaubų - šių dienų supratimu - suvokimas, bet ir tam tikras grobio žygių cikliškumas, tarsi kokia agresyvi akcentuoto kalėdojimo ar vogtinių vestuvių lytis, karo artumas su kraujo keršto papročiu. Mūsų neturètų stebinti karo ritualizavimas. Didžiūnai sueigoje svarstydami karo reikalus puotaudavo, žynys burdavo, teiraudamasis dievų valios, spėdamas žygio ar mūšio sėkmę ar nesėkmę, būdavo aukojami gyvuliai, duodamos priesaikos ${ }^{22}$. Apeigomis pradètas karas buvo apgau-

${ }^{19}$ HCL, p. 319:"...unusquisque tabulam ligneam ante se ex duobus asseribus compositam et clavam ad modum baculi pastoralis ad sustentaculum ipsius tabule... et cum exirent de tabulis suis ad compartationem lignorum ad incendium, plurimi ex eis a sagitarriis ledebantur...”

${ }^{20}$ Kariuomenès bruožai, p. 19.

${ }^{21}$ SRP, p. 107.

${ }^{22}$ Plačiau žr. kariuomenès bruožai, p. 10-16. 
biamas sakralumo skraiste. Be burtų neapsieinama ir žygio metu. Jie, bet ne pirmyn pasiųsti žvalgai suteikia žinių apie pasaloje tūnanti priešą ${ }^{23}$. Likimui nuspèti teikiama svarba sietina su tuo, kad mūšyje vadovaujamasi, vaizdžiai tariant, labiau garsu nei rega, kurios horizonto artumas, be abejo, siejosi su kovos būdu tankumynuose. Kalavijuočiams veržiantis i Lietuvą girdèti didelis besirenkančių karių riksmas ${ }^{24}$. Lietuviai, pastebėję, kad juos vejasi priešininkai, vienas kitą susikviečia garsiai šaukdami ${ }^{25}$. Garsas, sukeliamas riksmu, iečių ar kalavijų rankenų daužymu ị skydus, turedavęs sukurti atitinkamą įsiaudrinimo nuotaiką save drąsinant, o priešus bauginant. Toks šaukimas, o ne komandavimas H.Latvio vadinamas šaukimu pagal pagoniškus papročius ${ }^{26}$. Garso poveikis nebuvo paslaptis, kaip antai: siauroj proskynoj su lietuviais susidūrę kalavijuočiai puikiai tuo pasinaudojo pamokydami paskui juos ejjusius lyvius vokiškai šaukti27 ${ }^{27}$ Kitas psichologinio efekto pasiekimo būdas yra vaizdinis. Nemažai lietuvių karių, pamatę, kaip žvilga puolančiųjų ginklai, persigando, ėmė trauktis ir po trumpo susidūrimo pakriko "tartum avys"28. Siekdami įbauginti prūsus, apgulusius Šervenès pilį, kryžiuočiai ginklanešius apvilko riterių apsiaustais $^{29}$. Padejo tam tikri gestai: grūmojimas kalavijais ar kitais ginklais ir pan. Negalẻdamas sužinoti K.Vilinskio pateikiamos žinutès ${ }^{30}$ apie prūsų gebejjimą vesti mūšius, naudojant ragus, trimitus, švilpynes, karinius

${ }^{23}$ SRP, p. 153: "Tandem dum reertentes essent in vicino, primus Lethowinus in acie missa sorte clamavit: ve nobis male ibit negocium nostrum. Quem capitaneus increpavit, ut taceret. Ille autem non cessavit id ipsum clamare, quousque fratres cum suis de insidiis erumpentes insilirent in eos, et CCCL ex ipsis occiderent".

${ }^{24}$ ELK, p. 66.

${ }^{25}$ HCL, p. 298: “Quos ut viderunt pagani sese persequentes, rebus certis territi, simul omnes exclamaverunt clamore magno et convocantes suos in occursum revertuntur christianorum".

${ }^{26} \mathrm{HCL}$, p. 264: “... vooci-ferantur et constrepunt paganico more Lyvones...”

${ }^{27}$ HCL, p. 413; “... Theutonici primo venerunt ad prelium, et Leti omnes subsequebantur, clamantes, sicut edocti fuerant, lingua Theuthonicorum, ut caperent, reperent, interficerent. Quo clamore nimis territi Lettones et putantes multos sequi Theutonicos, conversi sunt in fugam..."

${ }^{28} \mathrm{HCL}$, p. 277: "Qui more militari tam in equo quam in se ipso bene loricatus, cum paucis qui aderant Theutonicis Lethones aggreditur. Sed ipsi, nitorem armorum istorum abhorentes, deo eciam timorem immittente ab eis ex omni parte declinant... Lethones de dei misericordia ita conterritos... undique per viam tamquam oves disperguntur...”

${ }^{29} \mathrm{P}+\mathrm{K}$, p. 184.

${ }^{30}$ Walki, p. 107. 
šokius, šaltinio, vis dẻlto remdamasis tuo, kas anksčiau mano parašyta, negaliu su tuo sutikti be išlygų, ypač dèl vèliavų. Garsiniai signalai buvo naudojami visose kariuomenėse, tačiau vẻliavų kaip vizualinių, veiksmus koordinuojančių ženklų racionalaus naudojimo vieta yra kautynės atvirame plote veikiant atskiriems taktiniams pulkams ${ }^{31}$. Pirmą kartą pačių lietuvių véliavą $1337 \mathrm{~m}$. mini Vygandas ${ }^{32}$. O kad ji nebuvo ịprasta dar ir $\mathrm{XV}$ a., rodo Vytauto prieš Žalgirio mūšį kariuomenei išdalytos vẻlia$\operatorname{vos}^{33}$. Sunkiai tikètiną vẻliavų turẻjimą XIII a. pagonių kariuomenèse galime remti amžininkų liudijimu: estams užpuolus Rygą, i pagalbą jūra plaukiantys kryžininkai iš didelio atstumo negalejo atskirti, kur yra pagonių, o kur krikščionių kariuomenè, tuomet pastarieji pakèlè vẻliavas ir padèjo jiems susiorientuoti ${ }^{34}$.

Veiksmų koordinavimo sistemos menkumas eina ranka rankon su ypatingu santykio tarp vado ir karių suaktualinimu. Vado reikšmé istorinèje literatūroje yra aptarta ${ }^{35}$. Jam žuvus ar jị sužeidus, lietuvių bei kitų baltų kariuomenès nutraukdavo karinius veiksmus ir pasitraukdavo. Tuo tarpu kryžininkų kariuomenė, praradusi vadą, vyskupą Bertoldą, metasi siaubti Lyvių krašto ${ }^{36}$. Norèčiau akcentuoti tam tikrą skirtumą tarp kryžininkų kariuomenès ir lietuvių. Dažnai tenka remtis daugeliu atžvilgiu informatyviu pasakojimu apie Žvelgaičio kariuomenę. Tokio tipo kariuomenę drịcčiau pavadinti "miegančia" - kaip apie ją po dvejų metų pertraukos išsitarẻ kitas lietuvių kunigaikštis ${ }^{37}$, - jos veiklumas ištisai paniręs i grobio "surinkimą". Toks dèl grobio gausumo budrumą praradęs lietuvių būrys grịždamas iš Saremos sugule pogulio apsitvėręs ietimis. Ši greičiau maginė nei karinè saugumo priemonè neišgelbejjo karių nuo nakti-

${ }^{31}$ Prūsų vėliavos”, p. 24-27.

${ }^{32}$ Wigandi. p. 5: “... telo igneo vexillum combusit...”

33 Žr. išn. 15 I c.

${ }^{34}$ HCL, p. 359: "Qui et appropinqua-verunt add Dunam, et viderunt ostes coram se in littore maris et in alio littore Rigenses, et non cognaverunt, quia christiani erant, sed signum dabant eis Rigenses vexillorum demonstratione”.

${ }^{35}$ Kariuomenès bruožai, p. 5-6.

${ }^{36}$ HCL, p. 264: "Amisso etenim capite suo nimirum turbatur exercitus, et tam equis quam navibus tam igne gladio Lyvonum perdunt segetes".

${ }^{37}$ HCL, p. 298: "Ascendens autem dux exercitus cum comitibus suis vicinius ad castrum, et ait: "Vade, nuncia christianis, qui ante duos annos exercitum ab Estoniam redeuntem quasi dormientem interfecerunt, nunc me et omnes meos vigilantes invenient". 
nio susidorojimo su jais ${ }^{38}$. Iš tiesų visuotinai yra sutariama, kad baltų genčių nobiliai yra buvusi karine klasẻ. Priklausymas karinei klasei pats savaime lygio nesukuria. H.Latvis žiemgalių kunigaikštị Viestartą vadina karingu vyru, tačiau tas karingas vyras, ketindamas užpulti lietuvius, prašo rygiečių, kad jam duotų vyrų, nusimanančių karo reikaluose ir mokančiu valdyti ir rikiuoti kariuomenę ${ }^{39}$.

Manyčiau, kad kintanti geopolitine padėtis karybos srityje konkrečiai pasireiškẻ tuo, jog vis dažniau kariams tekdavo susidurti su kariais. Keršto žygis igauna ginkluoto abiejų pusių susirėmimo pobūdị. Tokiame žygyje karvedys ne tiek vedlys, kiek karžygys. Iš jo tikimasi ypatingos drąsos ir jis pats ikvepia karius kovai ${ }^{40}$. Jo kovingumas - jo autoriteto šaltinis. Galime spèti, kad pašventintas karas - tai tarytum savotiška hekatomba; ne pro šali paminèti pasitaikiusius priešo aukojimus ant laužo ${ }^{41}$. Pašventinto karo atlikejjo vaidmuo yra dvejopas. Jis - žynys ir karys. Ko gero, Lietuvos didžiųjų kunigaikščių atlikti aukojimai ${ }^{42}$ nebuvo atsitiktiniai. Apie sūduvių vadą Skomantą Ipatijaus metraštis tiesiai sako, kad jis buvęs žynys, "Skomond bo bie volchv i kobnik naročit, borz že bie jako i zvier', prieš bo chodia povojevaziemlu Pinskuju"43. Matyt, čia turima galvoje bendra sėkmé, kurios šaltinis - konkretus asmuo. Kol sẻkmé lydi vadą, tol jos apglėbiami yra ir kariai. Vedami kariai kovoja ir jie kovoja už vadą. Pastarajam žuvus ir dẻl to sutrikus kovai, dedamos pastangos atgauti jo kūną ${ }^{44}$ Kad išskirtinè svarba teikiama ypatingam asmeniui, matyti iš to, jog prūsai, puldami Bartenšteino pili, įvairiausiais būdais sten-

${ }^{38}$ ELK, p. 55.

${ }^{39}$ HCL, p. 276: “...Vesthardus... vir bellicosus ... rogat sibi saltem aliquos dari viros doctos in bello, qui exercitum sciant regere et ad pugnam informare”.

${ }^{40}$ SRP, p. 62: “...Pyopso, quidam Pruthenus capitaneus Warmiensium, congrefata omni potencia exercitus sui, dictum castrum Balgam obsedit et quia caput fuit aliorum, ipse velut dux belli pre aliis in prelio se voluit ostentare..."

${ }^{41}$ Wigandi, p. 154.

42 Žr. Studia, p. 326-327.

${ }^{43}$ PSRL, t. 2. 182.

${ }^{44}$ SRP, p. 190:”... et quendam virum nobilem acciderunt, quem cum Lethowini deportare vellent fratres per crebra jacula defenderunt. Tandem provocati in iram omnes convenerunt, quidam ipsum mortuum cum brachiis, alii cum pedibus, reliqui cum capite rapietes, violenter deportaverunt. Sed antequam hoc perficerent, tot ex eis vulnerati fuerunt quod eorum numerum non audivi”. 
giasi išvilioti Miligedą ${ }^{45}$, kurio žuvimas, jų nuomone, atimtų igulai pusę jėgu. Vien tuo grindžiamas paklusnumas, tiksliau - vado kovingumo imitavimas buvo žingsnis pirmyn. Mums praverstų Ibrahimo ibn Jakubo pasakojimo apie prūsus ar panašus apibendrintas J.Dlugošo interpretavimas apie jotvingius ${ }^{46}$. Prūsas, kai užpuola jo kraštą, nelaukdamas draugu vienas kalaviju kertasi su priešais kol žūsta. Tokia pirma reakcija, nepaliekanti nei laiko, nei galimybių susitelkti, eliminuoja logiką, būtiną valdyti staigiems veiksmams. Nesusiderinus lietuvių ir haličènų žygiui ị Kijevą, pirmieji ilgai nesvarstydami smarkiai tūžo ir iš vakar dienos sajungininkų tapo šios dienos priešininkais ${ }^{47}$. Prieš Kryžiuočių ordiną sukilusio sembų Rinavos valsčiaus gyventojai, manytume, yra labai drąsūs ${ }^{48}$. Dar drąsesni buvo galindai, kurie, paklausę savo viešpaties, beginkliai užpuolẻ kaimynų krikščionių žemes ${ }^{49}$.

Kartais pasitaikydavę stipresniji nustatyti - kaip kad prie Vorutos pilies - vien iš karinès jègos demonstravimo ${ }^{50}$. Tai mums leidžia kovą įvardinti kaip tam tikrą psichomachiją, kas ypač akivaizdu, kai kova su priešu nesibaigia jo mirtimi. Fizinè mirtis nèra galutinè, priešui turi būti sutrukdyta kelionè į dausas, ką ir daro žiemgaliai, kraudami žuvusių lietuvių

${ }^{45}$ PŽK, p. 160. SRP, p. 64: "Idem Fomanda ... rediit ad suos compatriotas Pruthenos, simulans se hostem fidei at fidelium, quo viso Frutheni gavisi sunt gaudio magno, quia sperabant omnem virtutem fratrum per hujus viri industriam enervare”.

${ }^{46}$ Lowmianski H. Prusy - Litwa - Kryzyžacy. W., 1989, p. 66.

${ }^{47}$ PSRL, t. 2, p. 195: lietuviai "ni vidiša ništo, tokmo i golovne tu, psy tečiušče po gorodiščiu i tužachu že i plevachu po svoiski rekušče: “janda”, vzyvajuščia bogi svoja, Andaja i Diviriksa, i vsia bogi svoja pominajuščia, rekomyje besy”. Nors apibendrindami, plaukiantys iš dviejų pavyzdžių niekad nèra ịtikinami, vis dèlto kaip signalą, drịstu priminti panašios situacijos atveji, kai buvo pavestas Gediminas: Wigandi, p. 24: “...irati cogerunt regem Polonie sibi salaria in auro, argento, panno et equis largiri, cuilibet secundum sua merita et sic reversi sunt in patriam".

48 PŽK, p. 156-157.

${ }^{49}$ SRP, p. 52: “... prophetissa ... convocatis ad se pocioribus tocius terre, ait ad eos: dii vestri volunt, ut omnes sine armis at ferro vel aliquo defensionis amminiculo contra Cristianos bellum moveatis. Quo audito statim obediunt qui ad bellum habites fuerant, ad viciniorem Cristianorum teram leto animo sunt profecti”.

${ }^{50}$ PSRL. t. 2, p. 187. 
galvas ị roges ${ }^{51}$. Kerštaujantis Lengvenis paaukojo nukauto Cėsių komtūro galvą, parneštą i i Lietuvą nelaisven pakliuvusio riterio ${ }^{52}$. Kartais su priešo galva net ir pasikalbama ${ }^{53}$. Mano manymu, visa tai žymi karinių veiksmu r ribų pasklidimą. Tartu apgulties metu dienomis įnirtingai kautasi, o naktimis žaista kariniai žaidimai ir grota ịvairiais instrumentais ${ }^{54}$.

Tokio staigumo ir pasklidumo dominavimo ribą žymi ne tiek abstraktus laikas ir erdvé, kiek tam tikri visuomenès viduje vykstantys pokyčiai: gentinès visuomenès transformacija ị visuomenę, kurios politinè forma yra valstybè. Gentinès karybos glaudi sąsaja su kasdienybe pasireiškia ne tiek karo, kuris gal net intensyvesnis buvęs 14 a. nei 13 a., nuolatinumu laiko prasme, kiek silpnu organizuotumu, artumu papročiams, o visa tai, kartu paėmus, žymi karo dimensijos - sui generis - kaip tokios menką išsikristalizavimą. Dèl šios priežasties karingumas kaip pyktis tinkamai charakterizuoja gentinę karybą. Tam tikro organizacinio amorfiškumo ịveika yra valstybės susidarymas, dèl ko militarinè veikla specializuojasi.

Šio proceso išdava yra karingumo kaip jègos formavimas. Metaforiškai kalbant, karingumas kaip pyktis tarytum vandenynas, karingumas kaip jèga - iškylanti sala.

${ }^{51}$ HCL. p. 277: "Hunc Semigallorum quidam palpitare videntes, caput eius abscidunt, et vehiculis suis imponentes, que solis capitibus Lethonum oneraverant, in Semigalliam ducunt".

${ }^{52}$ ELK. p. 113.

53 SRP. p. 87-88: “... quidam vir deė Nattangia caput fratris Joannis vicekommendatoris predixit in lanceam et elavans in altum, ait: si tuo sano consilio acquievissent fratres tui, occisi utique non fuissent".

${ }^{54}$ HCL. p. 432: "Nulla requies conceditur fessis, diebus pugnant, noctibus ludos et clamores exercent. Lyvones cum Letthis concussione gladiorum cum clypeis conclamantes; The tonici in tympanis et fistulis et ceteris instrumentis musicis, Rutheni cum suis instrumentis et clamoribus noctes omnes insomnes ducunt". 


\section{Karingumas kaip jèga}

\section{Kariauna: bandymas nustatyti jos genezę}

Tiriant kariauną, tenka remtis ne vien rašytiniais šaltiniais, kurių duomenys ne visada esti pakankami rekonstrukcijai, bet ir bendromis analogijomis. Nuodugniai kariaunos problematiką tyręs H.Łowmianskis išryškina keturis būtinus bruožus, kurie išskiria kariauną iš kitų karinių pajẻgų rūšių: 1 - kariné veikla, 2 - kario aprūpinimo ir išlaikymo pagrindu organizuojama ekonomika, 3 - organizuotumas, išplaukiantis iš nuolatinio pasiruošimo veikti vado ịsakymu, 4 - ideologija, kai grupès savimonę atitinkantis "dvasinis saitas" pagrịstas savanorišku įsipareigojimu vienas kitą remti ${ }^{1}$. Visus šiuos keturis aspektus sieja artimas, asmeninis pagrindinių subjektų - vado ir karių - santykis. Lotyniškuose tekstuose kariauna yra vadinama comitatus (palyda, svita) terminu, kuris nurodo esminę kariaunos savybę: hierarchijos ir solidarumo sambūvị ${ }^{2}$ Keturi minèti bruožai yra pagrindas, pagal kuri skiriami trys kariaunų tipai: vienkartinè, nuolatinè, jei kariai nuolatos yra vado išlaikomi, ir tarpinè, kai kariai turi atskirus ūkius, bet yra susiję nuolatiniais "moralinio ir organizacinio pobūdžio ryšiais”. Šis tipas, H. Łowmianskio nuomone, vyravęs gentinėje baltų epochoje ${ }^{3}$. Karių vieningumui akstiną duoda bendras tikslas - grobis. Vieningumo pagrindas yra gyvenimas kartu, kurị legitimuoja genties dispozicijos institucijos: kraujo arba dirbtine, ritualo sukuriama, giminystè. Anot F. Cardinio, tai tarsi šeima, kuri yra sukurta karo ir karui ${ }^{4}$. Kariauninkai yra vadinami amici, vrunde, prijatieli, comitatenses, voi ir kt. Bene dažniausiai vartojamas "amicus", draugas, žymintis tiek giminaičius, tiek kito kilimo žmones ${ }^{5}$. Žvelgaitis, pasukęs į Rygą, yra lydimas savo bičiulių ("cum suis sodalibus"), o grižta pas savo sẻbrus, draugus $\left(\right.$ socios) ${ }^{6}$. Panašios reikšmės terminų diferencijavimas leidžia teigti, kad

\footnotetext{
${ }^{1}$ Łowianski H. Początki Polski (toliau - Początki).1970. t. 4, p.166.

${ }^{2}$ Kardini F. Istoki srednevekovogo rycarstva (toliau - Istoki). M., 1987, p. 105-107.

${ }^{3}$ Studia, p. 258.

${ }^{4}$ Istoki, p. 91.

${ }^{5}$ Studia, p. 258-263.

${ }^{6}$ HCL, p. 275.
} 
jis buvo nuvykęs su jam artimiausiais žmonėmis. Giminaičiai ir nelaisvoji šeimyna sudaro sutelkčiausią to meto karini vienetą, kuris H.Latvio ar P.Dusburgiečio ne vienu atveju yra vadinamas "familia"7.

Rusų metraščiuose artimiausia kariauna yra pavadinama "mažosios kariaunos" terminu. Lietuviams pralaimejjus mūšs prieš Daumanto vadovaujamus pskoviečius, kunigaikštis Gerdenis su mažąja kariauna pasprunka ${ }^{8}$. Mažoji kariauna iš tiesų nebuvo gausi. Baltų nobilių žemėvalda buvo ganètinai kukli, kas jokiu būdu neteikè pakankamai pajamų atskirame kieme išlaikyti gausesnei kariaunai. Grobio žygis, pereinantis gimininès organizacijos ribas, buvo dirva, teikusi turtą, kuris igalindavo i kariauninkų tarpą priimti juo suviliotus kilme svetimus žmones. Pirminèse kariaunose dauguma kilme svetimujų buvo ekonomiškai savarankiški ir gyveno savo ūkiuose. Tokia kariauna, kurios dauguma negyvena po vienu stogu, yra protokariauna, o jos elgesys paženklintas palaidumo. Tarp vado ir nelaisvosios šeimynos narių vyrauja vertikalūs, tarp jo giminaičių ir kilme svetimujų, nors ir dirbtine giminyste susietų, - horizontalūs ryšiai, ir šie persveria.

Funkciniu aspektu kariaunos prototipas yra plěšiku būrys'. Tipišku tokio pobūdžio būriu galime laikyti prūsų didžiūno Pipino, su "netikinčiaisiais" ịsikūrusio vienoje Kulmo žemès tvirtovèlèje, kariauną $a^{10}$. Didesni grobio žygiai buvo rengiami kelių sutelktų kariaunų. Kartojasi du atvejai: išrenkamas vienas bendras žygio vadas arba tenkinamasi visu kariaunų vadų vadovavimu. XIII a. palyginti dažnų lietuvių susidūrimų Rusijoje metu retokai minimas jų vadas. Atrodytų, kad priešininkams kai kada būdavę ganètinai sunku išskirti lietuviams vadovavusị asmenị. Kunigaikščiui Aleksandrui Neviškiui vienu metu nugalèjus septynias kariaunas (ratei), paminima, kad žuvusi "daugybe vaivadų" kitą kartą kovojant su lietuviais, jų kunigaikštukai paminimi tris kartus ${ }^{12}$.

Tokia padètis vadovavimą kariams mūšyje daro kebliu reikalu. Žinoma, kovoje susidurdavo gyvi žmonès, todèl nèra vieno ar kito privalomo elgesio kanono, tačiau pats organizacinis palaidumas beveik anuliuo-

\footnotetext{
${ }^{7}$ HCL, p. 351. SRP, p.113. žr. Studia, p. 264-265.

${ }^{8}$ PSRL, t.3. p. 59: “... tolko ubeža odin kniaz Gerden v male družine ..."

${ }^{9}$ Studia, p. 267.

${ }^{10}$ SRP, p. 55.

${ }^{11}$ PSRL. t.7, p. 151.

12 PSRL. t.4, p. 229.
} 
davo galimybę vadui savo kovingumo pavyzdžiu daryti lemiamą įtaką kovos eigai, nebent jo žuvimo atvejis rezonuotų didesniu dezorganizacijos laipsniu. Kai vadas renkamas, galima tikètis jo asmeninès kariaunos - draugų ir giminaičių - ištikimybės ir susiklausymo. Atskira kariauna buvo vado galybès pamatas, tačiau įmanoma, kad jai pražuvus ne tik kunigaikščio, bet ir jo palikuonių statusas nuvertètų iki neturinčių šansų būti pagerbtiems išrinkimu kitą kartą. Kaip tik dabar tiktų Dangeručio pavyzdys, remiantis spejjimą, kad net vyresniujų kunigaikščių padètis dẻl jų santykių su savo gimine ar bendrais ne visada buvusi tvirtai garantuota. Dangeručiui kalint Césių pilyje, atvykę iš Lietuvos kai kurie jo draugai turbūt praneše kažką nemalonaus, nes po to jis persismeige kalaviju ${ }^{13}$. Tik herarchine kariaunų struktūra - ir viduje, ir išorejje - lėmè dalijimąsi bendra atsakomybe. Nesant herarchijos laiptų, kovos lauką palikęs kariaunos vadas ar žemesnis kariauninkas negalejo būti paprastai eliminuotas ir nubaustas.

Remiantis 1219 m. taikos su Voluine sudarymu, teigiama egzistavus lietuvių žemių konfederaciją. Paminėti penki vyresnieji kunigaikščiai, žinoma, buvo ir didžiausių kariaunų vadai. Remdamiesi istorine perspektyva, teigiame, kad klausimas, kuris iš vyresniųjų tapo didžiuoju, buvo laiko klausimas. Nors ir neįmanoma sužinoti konkrečios postūmio priežasties, bet šiuo atveju svarbiausią vaidmeni, kad didžiuoju tapo būtent Mindaugas, o ne kas kitas, suvaidino jo talentas. Lemtingas žingsnis buvo žingsnis ị valstybę, o tą laidavo lietuvių visuomenès brandumo pirmumas kitų Pabaltijo genčių atžvilgiu.

Barbariškose visuomenėse valdžios ịtvirtinimo būdas yra karinės jègos panaudojimas, kuris efektyviausiai atitinka tradicijos galią. Neblogai yra žinomi metodai, kuriais Mindaugas pasiekè valdovišką padėtị: žudydamas ar išvydamas gimines. İtvirtindamas savo padėti, pirmiausia jis turèjo įveikti giminaičių kariaunas ${ }^{14}$. Tai buvo ryžtingas judesys dirbtinès giminystès primato iškèlimo kraujo giminystès sąskaita vardan. Giminès anksčiau turèta valdžia susitelkia valdovo šeimoje. Susikūrus valstybei, didysis kunigaikštis tapo vyriausiuoju vadu, o jo kariauna - didžiausia jẻga. Ši jo padėtis kartu tampa paveldima ir nuolatinè, tik mirdamas valdovas nustoja juo buvęs ${ }^{15}$. Jis nėra pirmas tarp lygių ir turi didesnę

\footnotetext{
${ }^{13}$ HCL, p. 351: “... donec venirent quidam de Letonia de amicis eius ad eum. Post hec gladio se ipsum perforavit”.

${ }^{14}$ Plačiau žr. Gudavičiaus E. Kryžiaus karai Pabaltijyje ir Lietuva XIII amžiuje (toliau - Kryžiaus). V., 1989, p. 92-110; kariuomenès bruožai, p. 5; PSRL. t.2, p. 201.

${ }^{15}$ Kariuomenès bruožai, p. 6.
} 
laisvę savo nuožiūrai bei galią, kad jo valia būtų įvykdyta. Jo asmeninis dalyvavimas kovoje su priešais nėra besąlygiškai privalomas. Mindaugas siunčia savo kariuomenę, vedamą Sirvydo ir Chvalo, Vozviaglio link ${ }^{16}$. Kita vertus, niekas jo negalëjo sulaikyti nuo dalyvavimo žygyje ị Kuršą prieš Embulès pilį ar prieš Vykintą į Žemaitiją ${ }^{17}$. Vytenis, stojęs ị dvikovą su vokiečiais, Voplaukio mūšyje vos neprarado gyvybės ${ }^{18}$. Didžiojo kunigaikščio iškilimas aukščiau visu padejjo jam kai ką iškelti aukščiau kitų. Karvedžiu pasižymėjimas, jų sugebėjimai galèjo atkreipti palankią valdovo akị. Tai nutikdavo ne tik vietiniams pavaldiniams, bet taip pat ir kitagenčiams. Pabėgęs iš Riazanès, Ostafijus rado tarnybą pas Mindaugą, $1281 \mathrm{~m}$. žiemgalių kunigaikštis Nameisis vedẻ lietuvius į Sem$\mathrm{bac}^{19}$. Siuos sprendimus lèmé praktiškasis mastelis, o ne giminystės laipsnių artumas.

Kariauna kaip institutas, nesutampantis su giminès organizacija, buvo įtampos tarp priklausymo giminei ir ištikimybès karvedžiui židinys. Būtent tos įtampos poveikis buvo lemiamas kuriant Lietuvos valstybę, kas užbraukè gentinę-gimininę epochą. Kuo mūsų klausimui svarbi Treniotos mirtis? Tragiško Mindaugo likimo taip pat sulaukẻ du jo sūnūs, Ruklys ir Rupeikis, kuriu vienas buvo tiesioginis sosto ịpeddinis. Lietuvos monarchija, nužudžius valdovą, nesugrịžo ị priešvalstybinę būklę, sostas buvo tapęs ịvykusiu faktu. Nors Treniota kvietė Tautvilą pasidalyti Mindaugo palikimą, tačiau jie vienas kito nuoširdumu netikejjo ${ }^{20}$. Eiliuotosios Livonijos kronikos žodžiais, Treniota "buvo lygiai ir turtingas /ir tiek pat draugu turejo/ Mindaugas vos jam prilygo"21; ir jis tikriausiai pasirūpino pašalinti iš dvaro savo pirmtako artimiausius giminaičius ir šalininkus, kurie jam keltų rimtą keršto grèsmę. Pavojus tykojo visiškai netikètai. Treniotai einant i pirtị, jị nužudė Mindaugo kariai - "koniusi mindovgovi i porobci”22. Pasinaudodamas kariauninkų ištikimybe, Mindaugas sugebejo sukondensuoti giminès solidarumą ir nelaisvosios šei-

\footnotetext{
${ }^{16}$ PSRL. t.2, p. 195: “... Se bo beša liudie mindovgovi i vojevoda ich Chval ... i Sirvid Riuškovič ... “

${ }^{17}$ Kryžiaus karai, p. 82; PSRL. t.2, p. 188.

${ }^{18}$ Wigandi, p. 9: "Rex eciam, Wytan mala suscepit vix fugiens interfectus esset et capite truncatus manu cuiusdam fortis cruciferi ..."

${ }^{19}$ PSRL. t.2, p. 200; Kryžiaus karai, p. 165.

${ }^{20}$ Between, p. 5.

${ }^{21}$ ELK, p. 259-260.

22 PSRL, t.2, p. 202.
} 
mynos tarnišką paklusnumą. Dėl šios priežasties jo sūnui Vaišelgai lengvai pavyko sutelkti savo tèvo kariauninkus, draugus ${ }^{23}$. Nelaisvosios šeimynos modelis suvienijo ir giminaičius, ir kilme svetimus, laisvuosius ir nelaisvuosius. Treniotos negebejjimas apsisaugoti buvo apmokètas jo gyvybe.

Vertikalusis ryšys tapo dominuojantis ir jis gali būti, smarkiai neperdedant, eksplikuotas tẻvo-sūnaus ${ }^{24}$ ir davimo-gavimo santykių kategorijomis. Kariaunos vadas rūpinasi kariauninku, o šis remia vadą. Kario ištikimybė būdavo pasiekiama per jo aprūpinimą visa kuo. Tai tikriausiai bylojo Vytenio lūpos, kai jis kreipèsi ị nelaisvèn patekusius krikščionis, kviesdamas juos būti atsidavusius, o jis esą viskuo juos aprūpinsiąs ${ }^{25}$. Toks rūpinimasis, ko gero, persmelkdavo visas kariauninko gyvenimo sritis. Ibrahimas ibn Jakubas mini, kad lenkų valdovas Mieška lemdavęs, ką vesdavo ar už ko tekẻdavo jo kariauninkų sūnūs ar dukros ${ }^{26}$. Kronikininkas Orderikas pasakojo, kad Anglijos karalius Henrikas I ištikimai tarnavusius karius apdovanodavęs ne tik turtais, bet ir žuvusiųjų žmonomis ir dukromis ${ }^{27}$. Panašų didžiojo kunigaikščio valios prasiskverbimą išduoda Jogailos 1387 m. privilegija Lietuvos bajorams, leidžianti savo nuožiūra tekinti dukteris, o Vaidilos ir Algirdo dukters Marijos sutuoktuvés remtu šio papročio senumą. Kunigaikštis ir jo palydovai maitindavosi keliaudami po kraštą, o ilgainiui iš vaišinimo papročio išsirutuliojo pasėdžio prievole $\dot{e}^{28}$. Puotavimas prie bendro stalo buvo svarbi kariauninku gyvenimo dalis; kituose kraštuose tai atspindi terminas "buccellarii" (duonos valgytojai), kuriuo būdavo pavadinami didikų klientai ${ }^{29}$. Aprūpinimas ginklais siekia dar Tacito aprašytą senovès germanų praktikuotą ginklų įteikimo jaunuoliui ritualą, ženklinantị jo brandą ${ }^{30}$. Karolingų laikų šaltiniai atskleidžia daug ką paaiškinančią detalę. Valdovo parūpinti kariui ginklai, pastarajam žuvus ar pereinant tarnauti pas kitą siuzereną, turejjo

${ }^{23}$ PSRL. t.3, p. 58: Vaišelga “... sevkupi okolo sebe voi otca svojego i prijateli ...”

${ }^{24}$ Dudy G. Evropa v sriednije veka. Smolensk. 1994, p. 17-22.

${ }^{25}$ Wigandi, p. 7: "Omnes vos captivi mei modo debetis mihi adherere et mecum contra fidem pugnare cristianum et ego subveniam vobis in omnibus ..."

${ }^{2} 6$ Studia, p. 371-372.

${ }^{27}$ Chivalry, p. 68.

${ }^{28}$ Jurginis J. Baudžiavos ịsigalèjimas Lietuvoje (toliau - İsigalèjimas). V., 1962, p. 177. ir 191.

${ }^{29}$ Contamine P. La Guerre au Moyen Age. (toliau - La Guerre). Paris. 1992, p. 96. Atitinkamai senjorai - "hlaford" - duonos davejai, p. 97.

${ }^{30}$ Chivalry, p. 66. 
būti grąžinti, idant valdovas galètu juos suteikti kuriam kitam. Šie brangūs ginklai - kalavijas, žieduotis, šalmas - buvo išskirtinumo ženklai, nes eilinio kario ginklai, kaip minèta, buvo skydas ir ietis ${ }^{31}$.

Kariaunos sudètis kito, ji buvo nuolat atnaujinama; žuvus draugams, jų vietos nelikdavo vakuojančios. Vadinasi, kariaunoje dominavo jauni, nevedę vyrai - "pačiame jègų žydèjime"32. Jų kilmè buvusi marga - nuo šeimynykščio iki nobilio, tačiau ryši su valdovu lėmé ne tiek jų kilmé, kiek tarnavimas. Būdami visa kuo priklausomi ir turintys šiokią tokią socialinę perspektyvą, kariauninkai buvo valdovo atrama, kiti jiems ištikimybe neprilygo, būdami gerai ginkluoti kariai, jie buvo kovingiausia karių dalis. Gresiant mirtinam pavojui, kunigaikštis Margiris savo palydovų buvo pridengtas skydais ${ }^{33}$. Ne tiek svarbu, kad tokia ištikimybė grịsta paklusnumu, o ne riteriško kodekso intertišku suvokimu, tačiau jos įtaka yra svarbus veiksnys kovos įsipareigojimams. Šių karių ryžtas kovoti tampa pastovesnis priklausomai nuo žygio - grobio ar keršto - pobūdžio, dievų valios ir pan. Skirtumas tarp XIII a. pr. karių ir XIII a. II pusès didžiojo kunigaikščio karių taptų akivaizdesnis palyginus atotrūkị tarp Žvelgaičio gyrimosi ir jo darbų bei Traidenio grasinimų livoniečiams ir jo kariuomenés pergalių, juolab kad ir sunkių, Karūzos ir Aizkrauklès mūšiuose ${ }^{34}$.

Kuršių kariuomenẻ kovų prie Rygos metu daugiau laiko praleidžia laidodama savo žuvusius nei išties kovodama ${ }^{35}$. Traidenio kariuomenè, sunkiai laimejjusi Karūzos mūšį, nepasirūpina tokia "smulkmena" (!) ir palieka ant ledo daugiau nei pusantro tūkstančio žuvusių karių nepalai$\operatorname{dotu}^{36}$. Vadovaudamasis tuo, kas parašyta, manyčiau, jog P.Dusburgiečio literatūriniai posakiai apie pasikorusius dẻl nesėkmès lietuvius nepagrịs$\mathrm{ti}^{37}$. Vienas Ragainès pilènas, ketinęs išduoti Lietuvos valdovui Skalvių pili, tikisi igyti pasitikejjimą, laiduodamas gyvybe numatomą žygị (sub pena capitis $)^{38}$. Atsakomybe galva tapo realybe.

\footnotetext{
31 Ten pat, p. 67.

32 İsigalejimas, p. 122.

${ }^{33}$ Wigandi, p. 51: "Rex tamen a suis clientibus cum schutis protectus ..."

${ }^{34}$ Liv - Esth - Curländisches Urkundenbuch nebest Regesten, Herausgegeben von Dr. Fr. G. von Bunge, Bd.I.Reval, 1835. sk. 628: “ Quibus rex respondit animo indignanti: “... videbitis respectu ilius, quod ... peragamus in futuro".

${ }^{35}$ HCL, p. 318-320.

${ }^{36}$ ELK, p. 289.

${ }^{37}$ SRP, p. 153: "Alii fugerunt, et in solitudie quidam pre tristicia se suspenderunt ..." ir pan.

${ }^{38}$ SRP, p. 157.
} 


\section{Pašauktinės kariuomenės formavimas}

Susikūrus valstybei, didžiojo kunigaikščio valdžia įsitvirtino netolygiai ir skirtingu laiku palietė skirtingas jo valdas tiek teritoriniu, tiek socialiniu aspektu. Valdžios ịtvirtinimo ịrankis buvo kariauna, kuri, H.Łowmianskio teigimu, buvo pagrindinis valstybės sudarymo veiksnys ${ }^{1}$. Ji buvo šios iniciatyvos kilimo šaltinis. Valstybė buvo kuriama ne tiesiogiai gimininei bendruomenei priklausančiomis priemonemis. Inicijuojantis veiksmas sukẻlẻ procesą, kurio eiga žymi visuomenẻs struktūros kitimą, derantị karo poreikiams. Vis dèlto čia susiduriame su tam tikra dialektika, kai veiksnys yra veikiamas. Tatai H.Lowmianskio yra pavadinama vienu iš daugelio "abipusio ịtakojimo" pavyzdžiử.

Ankstyvosios valstybės stadijose maždaug apie 13 a. vidurị karinių pajègų telkimo centrai nors yra tie patys - kariauna ir žemès kariuomené, - tačiau jau vyksta ir tam tikri pokyčiai, įveikiantys išcentrines tendencijas. Išcentrinès tendencijos buvo tvirtinamos kuriant hierarchinę kariaunų struktūrą ir nuginkluojant liaudį.

Minėta, kad Mindaugas pirmiausia turèjo įveikti jam prieštaraujančias kariaunas. Nežuvusios, iš krašto nepabėgusios jos turejo jam paklusti ir įeiti ị didžiają kariauną. Šiuo metu didžiojo kunigaikščio kariuomenė yra jam paklususių kariaunų visuma. Ši kariauna plačiaja prasme buvo valdovo patiketinių rinkimo arena. Sunku pasakyti, iš kur daugiau kilo jo valios vykdytojų - iš asmeninės didžiojo kunigaikščio kariaunos ar iš jam paklususių kariaunų vadų. Iškilti galèjo tiek paprastas valdovo aplinkos žmogus, ką rodo Vaidilos ar vokiečiu riterio Gedimino belaisvio pavyzdys ${ }^{4}$, tiek didžiojo kunigaikščio valdžią pripažinęs vietinès diduomenès atstovas ar kunigaikštis, ką rodo Parbaus pavyzdys ${ }^{5}$. Karinè ir valstybinè tarnyba buvo tarpusavyje glaudžiai susipynusios, todèl iš tos pačios aplinkos buvo skiriami ir karo žygių vykdytojai, atskirų kariaunų vadai, kaip Sirvydas ir Chvalas ar Traidenio broliai ${ }^{6}$.

\footnotetext{
${ }^{1}$ Studia, p. 267.

${ }^{2}$ Istoki, p. 248:"Pričiom v takoi stepeni, čto nie občiestviennyje potriebnosti diktovali formy vedienija voiny, a struktura samovo občiestva byla podčiniena potriebnostiam voiny”.

${ }^{3}$ Początki, p. 151.

${ }^{4}$ Studia, p. 171; Gediminas, p. 101-104.

${ }^{5}$ Kryžiaus karai, p.97, 102.

${ }^{6}$ PSRL. t.2, p. 195 . ir sk.p. 871.
} 
Kariaunų hierarchija užtikrino kariauninkų verbavimo krypties vientisumą, tuo užkirsdama kelią lygiagrečiai formuotis vienai ar kelioms, tolygioms ar subordinuotoms kariaunoms. Treniotos atvejis rodo ir silpnąsias, ir stipriąsias ankstyvosios monarchijos puses.

Vieno valdžios šaltinio, paremto vienos kariaunos dominavimu, išsikristalizavimas sutelkẻ galią dinastijos ir valdovui artimiausių žmoniu rankose ir kartu nutildẻ genties sueigose kilmingụjų, galẻjusių manipuliuoti liaudimi, kuri neturejo sugebejimo valdytis, tuo labiau valdyti, bal$\mathrm{są}^{7}$. Galbūt šiuos pokyčius galime sieti su pirmuoju liaudies nuginklavimo etapu. Nuginklavimas nesuprastinas pažodžiui: niekas iš bendruomenininkų jų turimų ginklų neatiminejjo, tai reiškè, kad jų kaip pavaldinių padètis nesikeičia. Didžiojo kunigaikščio kariauna igauna persvarą, garantavusią jai viešẻimą, nestabdomą pasipriešinimo pavojaus. Senasis atvykusio kunigaikščio paprotys virto posėdžio prievole: "apdovanoti" yra būtina. Grobio žygis praranda būtinybės akcentą, kai grobis yra namuose, o ne svečiuose. Valdovo dispozicijai priklausantys ištekliai užtikrina nuolatinès ir gausios kariaunos išlaikymą, kuri savo ruožtu laiduoja ištekliu srauto nenutrūkstamumą. Atsirado galimybė įvesti "naujoves" transformuojant "senovę".

Prievoliu įvedimas yra tiesiogiai susijęs su feodalinès pašauktiniu kariuomenès valdovo formavimusi. Kario išèjimas iš kariaunos dèl amžiaus, vedybų ir panašių priežasčiu buvo pasitraukimas iš aktyvaus karinio gyvenimo ir sugrįžimas ị aplinką, iš kurios išeita.Pašauktine kariuomené rèmèsi pamatu, garantuojančiu kario pasirengimo lygị nepriklausomai nuo jo asmeninių santykiu su valdovu. Didžiojo kunigaikščio asmeninei kariaunai būdingi keturi klasikinès kariaunos bruožai. Tuo tarpu pavaldžioms kariaunoms valdovo atžvilgiu stigo bendro gyvenimo prie vieno židinio bruožo, tačiau tiesioginio vado atžvilgiu jos turẻjo visus keturis aukščiau minètus bruožus. Cia turime reikalą su išsklaidytos kariaunos reiškiniu ${ }^{8}$. Valdovui pavaldžių kariaunų lokalizacijos vieta buvo atskiros pilys, iš kurių buvo vykdoma jo valdžia'. Dèl šios priežasties tokios kariaunos yra vadinamos vietininku kariaunomis. Didžiajam kunigaikščiui atsakingas vietininkas rūpinasi pilies išlaikymu ir funkcionavimu. Keliau-

\footnotetext{
${ }^{7}$ Studia, p. 169.

${ }^{8}$ Początki, p. 170.

${ }^{9}$ Miskiewicz B. Podstawowe etapy rozwoju polskich sil zbrojnych do polowy XV mieku/SMHW. 1982. t. 25 , p. 54 .
} 
jančios kariaunos nereguliariai renkamas poseddis virsta stacija, nustatyto kiekio ir kitų gėrybių duokle, valstiečių suvežama ị pilị ${ }^{10}$.

Dèl rašytinių XIII a. šaltinių, liečiančių rytų Lietuvą, stokos bandykime pasekti didžiojo kunigaikščio pilių formavimosi proceso Panemunejje pėdsakais. Žinome, kad Lietuvos didysis kunigaikštis tiesiogiai valde pietų ir pietryčių Lietuvą - domeną, Šiaurès Lietuva ir Panemunè pripažino jo nominalią viršenybę, o Žemaitija tik pakluso. Vadinasi, Panemunès regionas gentinès organizacijos vienvaldiškumo įveikimo problemos atžvilgiu yra informatyvus.

Apie XIII a. viduri per karus su Lietuvos didžiuoju kunigaikščiu išnyko žemaičių kunigaikščiai ir žemių valdymą perėmė vietinė diduomenè. Kadangi tarpusavyje diduomenè sutarè, jos aktyvų pasipriešinimą išorès pavojui liudija, tarkim, Durbės ir kitos pergalès prieš Kryžiuočių Ordiną. Tačiau valdymo, paremto sutarimu, pažeidžiamumas yra liūdnai pagarsėjęs. Štai įžeistas Pelužis užtarimo kreipèsi ị kryžiuočius ir su jų pagalba atkeršijo už skriaudą, pražudydamas septyniasdešimt kunigaikščių ${ }^{11}$. Priešininkų vidinès nesantaikos išnaudojimo pasekmès gali būti nebepataisomos. Ragainès komtūras Liudvikas Libencelè nuolatiniais antpuoliais privertė lietuvius, gyvenusius Nemuno pakrantėje nuo Neries upès iki Lamatos žemès, mokèti duoklę, o jo patraukti Žemaitijos kilmingieji i kovą prieš Lietuvos karalių kurstẻ paprastus žmones ${ }^{12}$. "Susigiedojimo" užuomazgos nuslopino didžiojo kunigaikščio reakciją. Tai siejama su Gedimino pilies pastatymu Pagraudès valsčiuje ir vietininkų Mansto, Sudargo ir Mažono veikla Žemaitijoje ${ }^{13}$. Atspara panašiai grèsmei turẻjo būti pilių sistemų panemuneje ir prie Jūros upès sukūrimas. Kol kas keletas žodžių apie bendruomenines pilis.

Baltų genčių teritoriją sudarydavo žemès, o pastarąsias - valsčiai. Kiekviename valsčiuje būdavo po vieną pilį. Šių pilių statyba, priežiūra ir gynyba buvusi visų bendruomenininkų reikalas. Šiuos karius J.Jurginis

\footnotetext{
${ }^{10}$ İsigalejimas, p. 178.

${ }^{11}$ SRP, p. 149.

12RP, p.159:"...eciam nobiles per quos Semethia tunc regebatur, populum communem contra regem Lethowinorum provocarent, sic quod pluribus vicibus convenerunt contra regem ad bellum, ubi aliquando in uno conflictu centum vel CC vel plures ex ulraque parte caderent intefecti”.

${ }^{13}$ Gediminas, p. 16-18.
} 
vadina bendruomenès nariais - pilènais ${ }^{14}$. Taikos metu, kas būdavę retas reiškinys, tokios pilys greičiausiai visiškai ištuštėdavo. Pavojaus atveju jose slèpdavosi apylinkès gyventojai. Valsčiaus sueigoje sprendžiami pilies gynimo klausimai. Vienas kuris nobilis tam tikram laikui paskiriamas atsakingu už pili, paskui jo pareigos pavedamos kitam ${ }^{15}$. Tuo metu pilyje galejo būti keli kilmingieji, ką remtų Sudargo sūnaus pakliuvimas i nelaisvę Draikai išdavus Aukaimio pilį kryžiuočiams ${ }^{16}$. Aukaimio pilies išdavikai Draika ir Svirtilas ar Pūtvès pilènas Spūdas tik kryžiuočių padedami galejo jiems "perduoti" pilis ${ }^{17}$. Šie pilènai yra žemès kariuomenès kariai.

Sąvoka "pilènai” (castrenses) yra alternatyvi, galinti reikšti ir pilyje esančius žmones, ir socialini sluoksnị ${ }^{18}$. Prūsų Rogovo pilaitės gynèjai vadinami pilènais, lietuvių Kolainių pilies igula - taip pat. Kokybinị skirtumą galime suvokti, palyginę organizacinị skirtumą su aprašytuoju aukščiau.

P.Dusburgietis aprašo lietuvių pilių saugojimo paprotị: tam tikrą laiką, ménesi ar daugiau, pilis yra saugoma karių, kurie keičiami kitų ir t.t. ${ }^{19}$ Šie kariai vadinami apsiginklavusiais (armigeros), o juos paskiria ne genties sueiga, bet didysis Lietuvos kunigaikštis; suprantama, kad asmeniškai valdovas netvarke kiekvienos pilies, tai buvo pavedama vietininkams. Vietininkų ir jų artimų giminaičių veikimas išvien, kaip antai: Skaldonis, Surmino brolis, žūsta laivų kautynèse ties Veliuona, Mažono brolis gyne Žiesdytès pili ${ }^{20}$, minètas Sudargo sūnus remtų prielaidą, kad galbūt vietininkai - tai tam tikrų giminių, iggavusių ypatingą valdovo pasitikẻjimą, nariai. Lietuvių valdovo turtų valdytojas, patekęs ị nelaisvę, ža-

\footnotetext{
${ }^{14}$ İsigalejjimas, p. 89.

${ }^{15}$ Plačiau žr. Studia, p. 335-339.

${ }^{16}$ SRP, p. 167.

${ }^{17}$ PŽK, p. 250. ir 255.

${ }^{18}$ Pašauktinès bruožai, p. 64.

${ }^{19}$ SRP, p. 174: "Consuetudo ista apud Lethowimos in custodia castrorum, que sunt in terminis constituta, quasi communiter obsrvatur. Rex eorum ordinat aliquos armigeros ad custodiam alicujus castri ad terminum unius mensis vel amplius, quo completo recedunt, et alii seperveniunt ad custodiam supradictam".

${ }^{20} \mathrm{PŽK}$, p. 263 ir Gediminas, p. 17.
} 
dèjo kryžiuočiams, prisiekdamas galva, perduoti Gardino pilį ${ }^{21}$. Kryžiuočiai už savo patiklumą, kokị rodydavo Draikai ar Svirtilui, patys vos nesumokejo gyvybėmis. Surminas, Kolainių pilies seniūnas (capitaneus), vadovauja pilènams, kuriuos P.Dusburgietis vadina "karingais vyrais" (viri bellicosi) $)^{22}$. Dažnai vartojami epitetai "geriausieji", "rinktiniai", "stiprūs", "prityrę", apibūdinantys tiek pilių gynèjus, tiek žygiuojančius ị priešo teritoriją, yra taikomi tiems patiems kariams. Kaip galime spręsti iš Vytenio ịsiveržimo su 800 karių ị Lenkiją, tai buvo jo asmeninès kariaunos grobio žygis ${ }^{23}$. Tuo tarpu Voplaukio mūšyje jo kariuomenę sudare 4000 rinktinių vyrų ${ }^{24}$. Pasakyti, kad šiame žygyje dalyvavo ne vien asmeninè didžiojo kunigaikščio kariauna, nepakanka. Prisiminkime viršgentinès karinès organizacijos sukūrimą.

Ragainès kontūras Konradas Štangè su nedaugeliu karių žygiavo Veliuonos pilies link. Kryžiuočiai pasiuntè ị priekị žvalgybą, kad ištirtų pilènų būklę (ut investigaret statum castrensium) $)^{25}$. Sužinoję, kad visoje pilyje pilna karių, jie sutriko. Ko gero, ten jų buvo daugiau nei ịprastai. Kolainiu pilyje nuolat budèdavo 120, Bisenès - apie 80 kariụ. Pilies igulos, kuriai grèsdavo antpuolis, perduotas pavojaus signalas sutraukdavo i pagalbą kitu pilių gynejus. Galbūt taip galime suprasti svečių (hospites) termino vartojimą, žymintị ne šiaip svečius - vargu ar kryžiuočiams puolimo metu rūpètų tokius išskirti, - bet kitų piliu igulos karius, esančius užpultoje pilyje. Balgos komtūrui Henrikui Cutsvertui priartèjus prie Veliuonos pilies, joje buvę svečiai smarkiai ịniršo ir ginkluoti metėsi persekioti ${ }^{26}$. Toliau aiškejja, kad bent dalis svečių buvo raiteliai

${ }^{21}$ SRP, p. 177: "Hoc tempore quidam Lethowinus, qui camerarius fuerat regis Lethowinorum captus detinebatur in castro Balga, qui sub pena capitis sui obligavit se castrum Gartham tradere in manus fratrum, si a vinculis solveretur. Cui fratres credentes... ipsum abire libere permiserunt. Sed dum veniret ad regem, de his omnibus premunivit eum".

22 SRP, p. 152.

${ }^{23}$ SRP, p. 156.

${ }^{24}$ SRP, p.176: “...Vithenus rex Lethovie .... cum IIII milibus virorum preelectorum intravit terram Prussie".

${ }^{25}$ SRP, p. 157.

${ }^{26}$ SRP, p. 155: “...et ordinatis insidiis fratres de Raganita cum suis armigeris erecto vexillo processerunt ad dictum castrum, in quo tunc multi hospites fuerunt, qui, ex hoc multum indignati, armata manu ipsos hostiliter sequebantur...” pastebimas tokių igulų aktyvumas, p. 152, 160, 172. 
iš Aukaimio pilies. Kryžiuočiai, staigiai nužygiavę minètos Aukaimio pilies link, ten susidūre tik su pėsčiaisiais kariais, nes, kaip pažymi P.Dusburgietis, šio valsčiaus raiteliai prieš vieną dieną buvo išvykę ị Veliuoną, išgirdę brolių sukeltą triukšmą ${ }^{27}$. Būtent raiteliai yra karių dalis, žygiuojanti už savo valsčiaus ribų ar ị priešo teritoriją.

Tuo tarpu išsiskiria trisluoksnẻ karių hierarchija: tarp raitelių - "rinktiniai" kitų raitelių atžvilgiu, pastarieji - "rinktiniai" pėstininkų atžvil$\mathrm{giu}^{28}$. Mechanizmas, skiriantis bendruomenès karius raitelius ir karius pèstininkus, èmè veikti dẻl turtinès diferenciacijos, kurią didino ne atsitiktinis praturtẻjimas grobio žygyje, bet ilgalaikis karo ir darbo prievoliu vyraujantis telkimasis besiformuojančiuose socialiniuose sluoksniuose ${ }^{29}$. Darbo ir karo prievolių dualizams išliko iki pat XVI a., tačiau pradiniame etape socialinè poliarizacija ${ }^{30}$ sąlygojo tarpinio sluoksnio gravitavimą i besiformuojantị feodalų luomą arba ị būsimujjų baudžiauninkų klasę. Pirmiesiems, turtingesniesiems laukininkams darbo prievolès nebuvo didinamos karo tarnybos sąskaita, be to, jie gaudavo dali valdovo surenkamos centralizuotos rentos ${ }^{31}$. Antrieji pakeldavo ant savo pečiu pirmuju išlaikymo naštą. Dél tokios socialinès konjunktūros buvę kariauninkai likdavo kariais, turtingesnieji laukininkai tapdavo jais, ir, būtinai pabrèžtina, raitelių lygio kariais. Manyčiau, kariaunos įtaka, nelikviduojanti giminystės ryšiu svarbos, bet apibrèžianti erdvę, kurioje galioja turto ir tarnybos kategorijos, pasiekẻ bendruomenės organizacijos lygmenị. Čia vien prigimtis nedeterminuoja, kad koks žmogus gimęs šiame pasaulyje, toks bus ir aname ${ }^{32}$. Tai buvo pervalka, kuria ị prigimtinio elito būrị ịsiliedavo nebuvę nobiliai pagal prigimtị, bet buvę kariai pagal užsièmimą. Kariu telkimą iš bendruomenininkų patvirtina Ordino maršalas H.Dusmeris, drąsindamas saviškius būsimu mūšiu su tais, kurie nesiskiria nuo valstie-

27 Ten pat: "sed quia equites hujus territorii pridie iverut ad clamorem, quem fratres circa castrum Junigedam excitaverant solum pedites sequebatur eos...”

${ }^{28}$ Pašauktinès bruožai, p. 63-64.

${ }^{29}$ Ten pat, p. 44

30 Ten pat, p. 59.

${ }^{31}$ Gudavičius E. Lietuvos valstybès struktūra Gedimino laikais//Metai. 1992. Nr. 1 p.128.

${ }^{32}$ SRP, p. 54:"Credebant enim, si nobilis vel ignobilis, dives vel pauper, potens vel impotens esset in hac vita, ita post resurrectionem in vita futura". 
čių, mat geriausieji lietuvių kariai žuvę ties Bajerburgu ${ }^{33}$. Karių gretos taip pat buvo papildomos iš atleistinių 34 .

Šis procesas garantavo pašauktinès kariuomenès egzistavimą. $\mathrm{Su}$ ja sietinas kavalerijos, kaip taktinio kariuomenés vieneto, atsiradimas; žirgas tampa kovos priemone ${ }^{35}$. Vytenio kariuomenei $1311 \mathrm{~m}$. įsibrovus i Varmès vyskupystės žemes, kryžiuočiai drịsta ją užpulti tik surinkę pagrindines jẻgas $^{36}$. Didesnị karingumą lydèjo atitinkami organizaciniai pokyčiai, kai šalia atskirų žemių ${ }^{37}$ ar net pilių igulų ${ }^{38}$ užpuolimų tampa įprasti valstybės masto žygiai ${ }^{39}$. Organizacija, perimdama pavienių teritorinių junginių lokalines tradicijas, buvo reali politinę ịtaką užtikrinanti jẻga. Artejjantiems su magistru Medvėgalio pilies vyresniesiems buvo aišku, kad jie nebus išgelbèti, jei nebus apsaugoti nuo didžiojo kunigaikščio pykčio ir jẻgos ${ }^{40}$. Taigi kryžiuočių paskirų teritorijų užèmimo taktika buvo šachuota ir nuo užkariavimų pereita prie ilgalaikio karo, kurio naikinamieji metodai abiejų priešininkų pasidare panašūs ${ }^{41}$.

${ }^{33}$ LKK, p. 85 ir žr. Kariuomenès bruožai, p.21. išn. 83.

${ }^{34}$ Wigandi, p. 184: Bayores et libertini terram vestant igne...”

${ }^{35}$ Kariuomenès bruožai, p.20.

36 Ten pat, p. 21.

${ }^{37}$ SRP, p. 173: "Frater Voz...audiens quod Carsowite cum exercitu profecti essent contra fratres de Memela..."

${ }^{38}$ SRP, p. 154: “...fratres diverterunt iter suum versus castram Mederabam, de quo cristifideles multa incommoda passi fuerunt.

${ }^{39}$ SRP, p. 151 “...rex Lethowinorum cum octo milibus equitum intravit terram Sambiensem...”

${ }^{40}$ Wigandi, p. 18: "eo tempore multi pagani maiores de Medwalgen tract ant cum magistro, quod si eos a furore et potencia regis securare posset, omnes vellent ei obedire quia aliter non possent salvari; et abierunt pagani at revertuntur in pristinum errorem, sicut canis rediens ad vomitum".

${ }^{41}$ Lowmianski H.Agresja zakonu krzyżackiego na Litwę w wiekach XII-XV//Przegląd Historyczny, t.XLV. 1954, p. 348, 351. 


\section{I Š V A D O S}

Darbo užmojo išeities taškas - XIII a. pr. lietuvių gentinė karyba, o chronologinė riba - XIII a. pab.-XIV a. pr., žyminti kokybiškai naujos pašauktinès kariuomenès formavimąsi. Visus faktus siejantis dalykas yra valstybės susidarymo procesas. Išskiriamos dvi šio proceso dalys: laikas prieš valstybės susikūrimą ir po jo, tačiau ne tiek chronologine, kiek tipologine prasme. Pradiniame etape karinès energijos telkimo centrai buvo du: visuotinis visų žemés vyrų šaukimas krašto gynybai ir kilmingụjų kariaunos, kurių pobūdis buvo ofenzyvinis. Kariaunai karinè veikla imanentiška, todèl jai teikiamas pagrindinis dėmesys.

Žodžiais "karingumas kaip pyktis" gentinè lietuvių karyba apibūdinama dẻl kelių priežasčių. Pirmiausiai ị akis krenta grobio žygio visuotinumas, su kuriuo genetiškai yra susijusi to meto lietuvių karyba, pritaikyta grobti. Netikètas antpuolis ir staigus traukimasis buvo pagrindiné taktika. Tokia taktika žymi svarbų momentą: kario ginkluotos kovos su beginkliu vyravimą, o tai lemia, kad kaupiama patirtis yra labiau medžioklinè negu militariné. Patirties stoka paaiškina karių vengimą susidurti akis ị aki su ginkluotu priešininku ir vangų kovojimą priverstiems kovoti. Savos rikiuotès neturejjimas būdavo atsveriamas pastangų suardyti priešo rikiuotę, priverčiant ji kautis jam nepalankiomis aplinkybėmis gaivališkose kautynėse. Tokių kovų gynybinis pobūdis ryškus tada, kai iš anksto pastebejjus atsivejančius būdavo apsikertama miške.

Žygyje lietuvių kari galime pavadinti raiteliu, o mūšyje - pėstininku. Vadinasi, žirgas visu pirma buvo transporto priemoné, o karys - raitas péstininkas.

Dèl vokiečių riterių ordinų agresijos kintanti geopolitinė padètis bei vis intensyvesnẻ lietuvių karinè veikla kaimyniniuose kraštuose dažnina tiesioginị karių susidūrimą su kariais. Būtent šiuo atveju reikia paminėti rikiuotés užuomazgą, kuriai pradžią davė pėstieji, nuo žirgų nulipę kariai, o jos pačios nedidelis manevringumas savo funkcija yra artimas sukirstų medžių užtvarai. Vyraujantis raitelių vaidmuo ir toliau - bėgančio priešo persekiojimas.

Glaudus karo susijimas su kasdienybe žymi menką karo dimensijos išsikristalizavimą, jos susipynimą su papročiais, apeigomis ir pan. Tradicinę visuomenę persmelkianti maginè pasaulëjauta buvo naši dirva alogiškai karo - tarsi likimo spejjimo - eigai, kurio kilimo šaltinis būdavęs kraujo 
kerštas, agresyviai akcentuota kalėdojimo, medžioklès ar vogtinių vestuvių lytis. Išcentrinių tendencijų slopinimo mechanizmas buvo kuriamas dvejopai: kuriant hierarchinę kariaunų struktūrą ir nuginkluojant liaudị. Kariauna buvo ịtampos tarp priklausymo giminei ir ištikimybės vadui židinys. Kariauninkų telkimo principas buvo kraujo arba dirbtinė giminystè. Mindaugas, savo valdžią ịtvirtindamas karine jẻga, padarẻ ryžtingą žingsni dirbtinès giminystės primato iškẻlimo prieš kraujo giminystę ir sugebejo asmeninėje kariaunoje susieti giminès solidarumą ir tarnišką paklusnumą. Valdovas ir karvedys susilieja ị vieną asmeni, kurio padètis pakeičiama mirties, bet ne genties sueigos. Šitaip buvo užkirsta galimybẻ kurtis lygiagretiems valdžios židiniams. Kitų kunigaikščių kariaunos privalejjo paklusti ir įeiti ị didžiają kariauną. Konstatuodami kariauną peržengus tiesioginio asmeniškumo savybę, susiduriame su išsklaidytosios kariaunos atveju. Didžioji kariauna buvo valdovo patikètinių rinkimo arena. Iš jos kilo vietininkai, didžiojo kunigaikščio valią vykdę reziduodami atskirose pilyse.

Kariaunų hierarchijos nusistovẻjimą galime sieti su pirmuoju liaudies nuginklavimo etapu, kai jos kaip pavaldinių klasės dalia tampa nebeatšaukiama. Antrasis nuginklavimo etapas susijęs su pašauktinès kariuomenès formavimusi.

Kariaunos principas, transcenduojantis prigimties ribas, pasiekė bendruomeninès organizacijos lygmeni, pradedamas skirti karo ir darbo prievoles, kuo buvo padarytas kokybinis raitelių ir péstininkų bendruomenininkų skirtumas. Ši skirstymo sistema garantavo pilių su nuolatinėmis pilẻnų ígulomis funkcionavimą, ribojantị vietinị partikuliarizmą, taip pat kavalerijos atsiradimą.

Karingumas kaip jèga ima igyti kontūrus.

Kryžiuočių Ordino sustojimą ties Nemunu lėmė ne valsčiaus ar žemès, bet valstybès masto organizacijos veikimas. 


\section{Rašytiniai šaltiniai}

Scriptores rerum prussicarum. Leipzig, 1861. Bd. I (SRP)

Prūsijos žemès kronika, V., 1985.

Geneich Latvijskij. Chronika Livonii. M., L., 1938. Henrici Chronicon Livoniae (HCL).

Livonijos kronikos. V., 1991.

Eiliuotoji Livonijos kronika (ELK). Lietuvos Istorijos instituto vertimas ị lietuvių kalbą; mašinraštis.

Chronicon seu Annales Wigandi Marburgensis; ed J.Vooigt et E.Raczynski, Poznaniae, 1842.

Liv-Esth-Gurlandisches Urkundenbuch nebst Regesten, Herausgeben von Dr. Fr. G. von Bnge, Bd.I, Reval, 1853.

Tacitas P.K. Rinktiniai raštai. V., 1972.

Iordan. O proischoždienii i diejianijach gietov. M., 1960.

Drievnie - anglijskaja poezija. M., 1982.

PSRL - Polnoje sobranije Ruskich Lietopisei (PSRL), t. 1, 1927, t. 21843 , t. 31841, t. $41915, \quad$ t. 4 1917, t. 7 1856, t. 101965 , t. 151863.

\section{Li t e r a t ū ra}

Lietuvių karas su kryžiuočiais. V., 1964.

Ascikas K. Lietuviškas skydų tipas//Mokslas ir gyvenimas. 1978, Nr. 12, p. 26.

Baldžius J., Vogtinès vestuvès - "Darbai ir dienos", IX, K., 1940.

Batūra R. Lietuviškos taktikos reikšmė Žalgirio mūšyje. //Acta Historica Universitatis Klaipedensis. Nr.1. V., 1993, p. 65-77.

Dubonis A. Du šimtai pskoviečių Saulès mūšyje. //Lithuanistica 1990. Nr. 1, p.13-23.

Ekdahl S. Jono Dlugošo "Prūsų vèliavos" Žalgirio mūšio šaltinis. V., 1992.

Gudavičiaus E. Kryžiaus keliai Pabaltijyje ir Lietuva XIII amžiuje. V., 1989.

Gudavičius E. Dèl lietuvių žemių konfederacijos susidarymo laiko. // Istorija. Nr.24. V., p. 12-29.

Gudavičius E. Lietuvos valstybės susidarymo reikšmė Vokietijos "veržimesi i Rytus". // Lituanistica. 1990. Nr.3, p. 21-29. 
Gudavičius E. Lietuvos valstybės struktūra Gedimino laikais. // Metai. 1992. Nr.1, p. 125-129.

Gudavičius E. Kelios pastabos apie lietuvių taktiką Žalgirio mūšyje. // Karo archyvas. Nr.13, p. 34-43. V., 1992.

Gudavičius E. Lietuvių pašauktinès kariuomenès organizacijos bruožai. // Ten pat, p. 43-118.

Ivinskis Z. Lietuvos istorija. V., 1991.

Jurginis J. Baudžiavos įsigalejjimas Lietuvoje. V., 1962.

Kučinskas A. Kęstutis. V., 1988.

Mažeika R. Prekyba ir taika mirtis zonoje. LKMA. V., 1993. t. 14.

Nikžentaitis A. Gediminas. V., 1989.

Nikžentaitis A. XIII-XV a. Lietuvių kariuomenès bruožai. // Karo archyvas. Nr.13, p. 3-34. V., 1992.

Nikžentaitis A. Rašytiniai šaltiniai apie lietuvių pilių sistemą 13 a. pabaigoje - 14 a. pradžioje // MADA. 1986. t. 3. (96), p. 51-62.

Nikžentaits A. Lietuvių ir žemaičių santykiai 1283-1309 metais. // Mokslas ir gyvenimas. 1987. Nr.12, p. 13-15.

Ašcik K. O szyku bojovym bałt?w // Studia i materialy do historii wojskowošci (SMHW). 1970. t. 16.

Łowmianski H. Studia nad Dziejami Wielkiego Księstwa Litewskiego. Poznan. 1983.

Łowmianski H. Początki Polski. 1970. t. 4.

Łowmianski H Agresja zakonu krzyzackiego na Litwe w wiekach XII-XV. // Przegland Historyczny. T. XLV. 1954.

Łowmianski H Prusy - Litwa - Krzyzacy. W., 1989.

Miśkiewicz B. Podstawowe etapy rozwoju polskich sił zbrojnych do połowy 15 wieku. // SMHW. 1982. t. 25.

Paszkiewicz H. Jagiellonowie a Moskwa. t. 1. W., 1933.

Sikorski J. Zarys historii wojskowości. W., 1972.

Wiliński K. Walki polsko-pruskie w X-XIII w. Ł?dz, 1984.

Zająńczkowski S.M. Udział ludności wiejskiej w polskiej wojskowšci do połowy 15 stulecia. // SMHW. 1984, t. 27.

Christiansen E. The Northern Crusades. Minneapolis, 1980.

Keen M. Chivalry. London. 1984.

Mimford L. The City in History. N.Y. 1989.

Rowell S.C. between Lithuania and Rus': Dovmont Timofey of Pskov, his life and cult. //Oxford Slavonic. 
Papers. Nex series XXV. 1992.

Urban W. The Baltic Crusade. Dekab, 1975.

Urban W. The Samogitian Crusade. Chicago, 1989.

Der Deutsche Orden, von M.Tumler unter Mitarbeit von A.UDO. Marburg, 1981.

Contamine P. La Guerre au Moyen Age. Paris, 1992.

Delbruck H. Istorija voennogo iskustva v ramkach političieskoj istorii. T.3. M., 1933.

Kardini F. Istoki sriedniekovogo rycarstva. M., 1987.

Kirpičnikov A.N. Voennoje dielo na Rūsi v XIII-XV v. M., 1976.

Pašuto V.T. Obrazovanije Litovskogo gosudarstva. M., 1959.

Huizinga I. Homo ludens. M., 1992. Braudel F. Vriemia mira. T.3, M., 1992.

Duby G. Evropa v sriednijie vieka. Smolensk, 1994. 